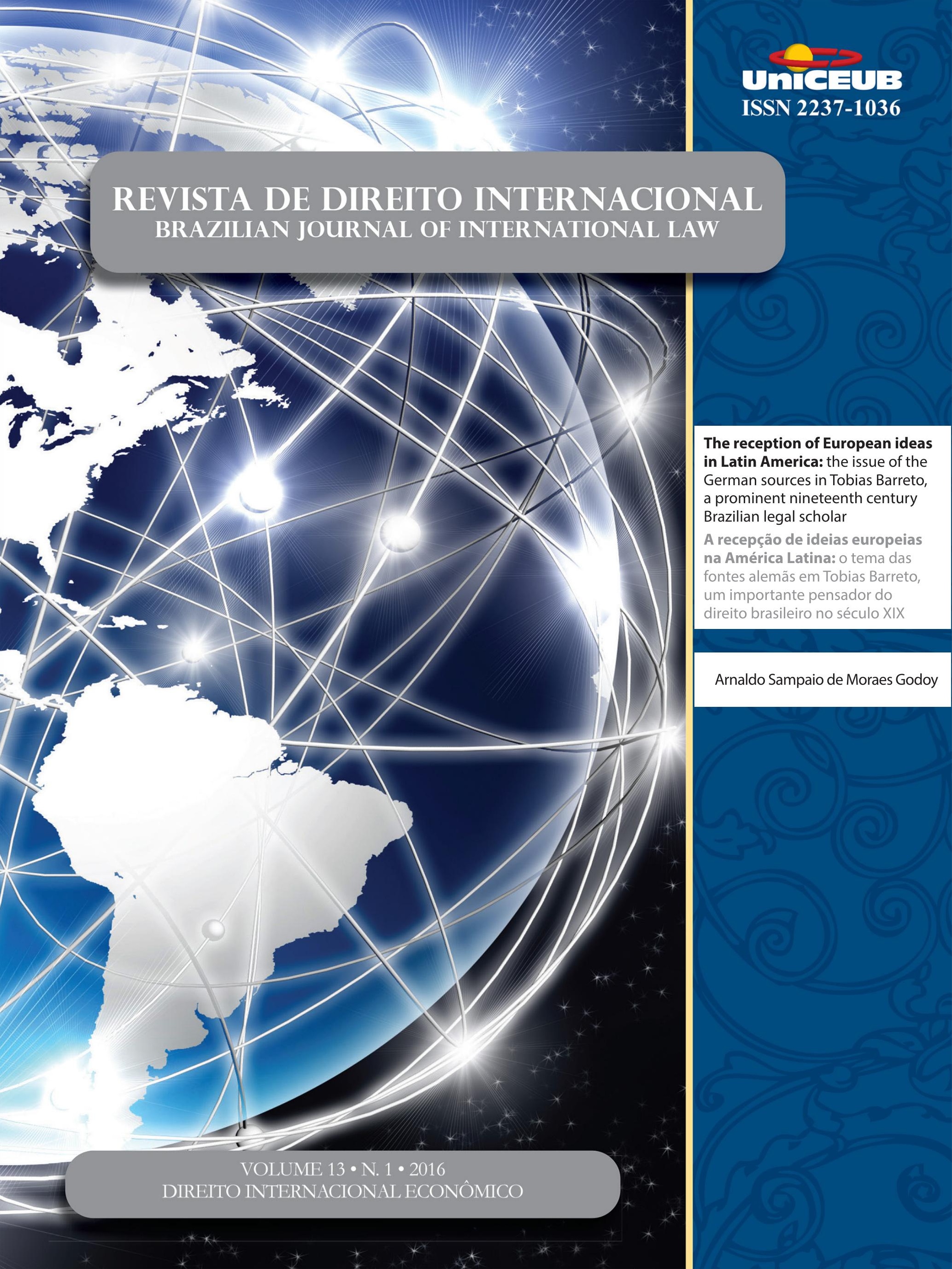




\section{Sumário}

Dossiê Temático: Direito Internacional Econômico.........................................................1

EDITORIAL:

Resultados da III Conferência Bienal da Red DEI ................................................. 3

Michelle Ratton Sanchez-Badin (em nome da Diretoria da Red DEI), Fabio Costa Morosini e Lucas da Silva Tasquetto (em nome dos organizadores da III Conferência da Red DEI)

Direito Internacional Econômico no Brasil: QUem Somos E o QUE faZemos? EvidênCIas EMPÍRICAS DE 1994 A 2014

Michelle Ratton Sanchez Badin, Fabio Costa Morosini e Inaê Siqueira de Oliveira

UM ESPAÇO PARA PENSAR EM ALTERNATIVAS? A ACADEMIA LATINO-AMERICANA DE DIREITO INTERNACIONAL ECONÔMICO FRENTE À ORDEM ECONÔMICA GLOBAL

Nicolás Marcelo Perrone

Grupo de alto Nível Brasil - Urugua (GAN): um Novo paradigma para a INTEgraÇão PRODUTIVA NO MERCOSUL

Alebe Linhares Mesquita e Vivian Daniele Rocha Gabriel

O COMÉRCIO de SERVIÇOS ENTRE Brasil E URUGUAI: LiberalizaÇÃo, DESAFIOS E PERSPECTIVAS DO SETOR DE TECNOLOGIA DA INFORMAÇÃO E COMUNICAÇÃO (TIC) E SOFTWARES

Vivian Daniele Rocha Gabriel e Alebe Linhares Mesquita

Core Labor Standards No Regime de PREFERÊNCIAS TARIFÁrias No MERCOSUL: A NeCESSIDADE DE HUMANIZAÇÃO DO COMÉRCIO INTERNACIONAL

Martinho Martins Botelho e Marco Antônio César Villatore

ACordo TRIMS: FleXibilizaÇão ou Não? Política de CONTEÚdo loCal, PROCESSO PROdUTIVO BÁSICO (PPB) E OS DESAFIOS PARA A INDÚSTRIA BRASILEIRA E A INTEGRAÇÃo LATINO-AMERICANA 100

Natália Figueiredo 
ESTUDIOS DE CASO DE RECHAZOS EN FRONTERA DE EXPORTACIONES ALIMENTARIAS LATINOAMERICANAS POR MOTIVOS RELACIONADOS CON MEDIDAS TÉCNICAS NO ARANCELARIAS.

Sofía Boza, Juan Rozas e Rodolfo Rivers

América do Sul em face dos tratados bilaterais de inVESTimento: RUMO aO RETORNo do EsTADO NA SOLUÇão DE CONTROvÉRSIAS? 133 Magdalena Bas

FutURo DE LOS SISTEMAS NACIONALES DE CIENCIA TECNOLOGÍA E INNOVACIÓN EN LA AGENDA ECONÓMICA DE AMÉRICA LATINA: DEFINIENDO CAMBIOS REGULATORIOS O PROTEGIENDO INVERSIONES 146

Rodrigo Corredor

EL PAPEL DE LAS INSTITUCIONES DE CONTROL FINANCIERO SOBRE LOS DERECHOS HUMANOS EN EL CONTEXTO LATINOAMERICANO 157 Jose Miguel Camacho Castro

CONVERGENCIA REgUlATORIA EN LA ALIANZA DEL PACÍFICO: UN CAPÍTULO INCONCLUSO 170 Rodrigo Polanco Lazo

O CONSTITUCIONALISMO E A COMUNITARIZAÇÃO NO DIREITO INTERNACIONAL: POSSIBILIDADES PARA O COMÉRCIO INTERNACIONAL?

Camilla Capucio

ESCASSEZ HÍDRICA E DIREITO INTERNACIONAL ECONÔMICO: O BRASIL COMO PROTAGONISTA NA TRANSFERÊNCIA DE ÁGUA PARA REGIÕES ÁRIDAS

Douglas de Castro

A Segurança energética como base para maior integração na América Do Sul: à espera DE UM TRATADO MULTILATERAL

Matheus Bassani

Outros Artigos. 246

As PRÁtICAS RESTRITIVAS DA CONCORRÊNCIA NO MERCADO DE CONTRATAÇÃo PÚBLICA EUROPEU .. 248 Alice Rocha da Silva e Ruth M. P. Santos 
Do TRANSNACIONAL PARA O NACIONAL: IOSCO, O MERCADO DE VALORES MOBILIÁRIOS BRASILEIRO E ACCOUNTABILITY

Salem Nasser, Nora Rachman e Viviane Muller Prado

MigRaÇÃo de TRABALHADORES INTELECTUAIS BRASILEIROS PARA O MERCADO INTERNACIONAL: IDENTIFICAÇÃO DE ATOS DE ALICIAMENTO DE EMPREGADOS E MECANISMOS LEGAIS PARA IMPEDIR A APROPRIAÇÃo TECNOLÓGICA E CONCORRÊNCIA DESLEAL ..........................................285 José Carlos Vaz e Dias e João Marcelo Sant'Anna da Costa

THE EASIER WAY TO HAVE "BETTER LAW"? THE MOST-SIGNIFICANT-RELATIONSHIP DOCTRINE AS THE FALLBACK CONFLICT-OF-LAW RULE IN THE PEOPLE'S REPUBLIC OF CHINA

Chi Chung

REFLEXOS JURÍDiCOS DA GOVERNANÇA GLOBAL SUBNACIONAL: A PARADIPLOMACIA E O DIREITO INTERNACIONAL: DESAFIO OU ACOMODAÇÃO 320

Valéria Cristina Farias e Fernando Rei

Matrizes Políticas da JUSTiÇA PENAL INTERNACIONAL. 341 Francisco Rezek

RESPONSABILIDAD INTERNACIONAL DEL ESTADO FRENTE A LUCHA CONTRA LA DISCRIMINACIÓN RACIAL Y ÉTNICA EN ESPAÑA. 348

Edilney Tomé da Mata e Eduardo Biacchi Gomes Correio

The Peace Process in Sierra Leone: an analysis on marriages between culture and CRIME

Gustavo Bussmann Ferreira

Funcionalização e expansão do Direito Penal: o Direito Penal negocial ...............376 Antonio Henrique Graciano Suxberger e Dermeval Farias Gomes Filho

Proteção Internacional do Consumidor e Cooperação Interjurisdicional .396 Héctor Valverde Santana e Sophia Martini Vial

The land rights of indigenous and traditional peoples in Brazil and Australia.... 418 Márcia Dieguez Leuzinger e Kylie Lyngard 
The reception of European ideas in Latin America: the issue of the German sources in Tobias Barreto, A Prominent nineteenth CENTURy BraZilian legal scholar........439 Arnaldo Sampaio de Moraes Godoy

Normas Editoriais ..................................................................................... 461 


\title{
The reception of European ideas in Latin America: the issue of the German sources in Tobias Barreto, a prominent nineteenth century Brazilian legal scholar*
}

\section{A recepção de ideias europeias na América Latina: o tema das fontes alemãs em Tobias Barreto, um importante pensador do direito brasileiro no século XIX}

Arnaldo Sampaio de Moraes Godoy**

\begin{abstract}
The paper explores the reception of European ideas in Latin America, exemplifying the argument through the philogermanism deffended by Tobias Barreto. It explores his personal library, in which there were many a German authors. In order to clarify this cultural reception, the research mapped the German authors with whom Tobias Barreto had some sort of identity and appreciation, especially as for Rudolf von Jehring.
\end{abstract}

Keywords: European ideas in Latin America. Philogermanism. Tobias Barreto.

\section{Resumo}

O ensaio explora a recepção de ideias europeias na América Latina, exemplificando o argumento por intermédio do filogermanismo defendido por Tobias Barreto. O ensaio explora os livros alemães de sua biblioteca. Com o objetio de clarificar essa recepção cultural a pesquisa mapeia os autores alemães com os quais Tobias Barreto compartilhava alguma forma de identidade e de respeito, especialmente no que se refere a Rudolf von Jehring.

Palavras-chave: Ideias europeias na América Latina. Filogermanismo. Tobias Barreto.

* Invited Author

** Habilitation (Livre-docencia) University of São Paulo-Brazil (USP). PhD, LL M, Catholic University of Sao Paulo (PUC)-Brazil. Law professor at Centro Universitário de Brasília-Uniceub-Brazil. Research done at the Max-Planck Institute für Europäische Rechtgeschichte, Frankfurt, Germany, december 2014. E-mail: asmgodoy@gmail.com.

\section{Preliminary Remarks}

This paper is an effort of illustrating the transposition and reception of European ideas and institutions in Latin America. It assumes European Law as a historical concept, irrespective of its geographical limits ${ }^{1}$. It also accepts

1 See, for all, DUVE, Thomas. European legal history: global perspectives. Max-Planck-Institute, 2013. Also, DUVE, Thomas. Von der Europäischen zu einer Rechtsgeschichte zu einer 
law as a keystone element of European culture ${ }^{2}$. In the context of sharing legal values in Western society ${ }^{3}$, the transposition of a legal framework (and the ideas that nurture it), however, may appear as an interchange that somewhat goes out of control, for there are also some random circumstances.

In the context of the paper, one does not know how receivers in Latin America valued European authors, books and ideas as significant. Some European books, authors and ideas that its beneficiaries in Latin America had chosen as canonical may end in a quasi-oblivion. It is not a rule, but the argument worth the discussion. In order to sustain it, the paper enhances an effort of finding and gathering some German sources that influenced Tobias Barreto (1839-1889), a Brazilian scholar concerned with German authors and ideas.

Notwithstanding Tobias Barreto's efforts towards a Brazilian reception of German intellectual stimulus, in both Philosophy and Law, the outcome was a mere rearrangement within the boundaries of European legal ideas and traditions, always moveable and contingent ${ }^{4}$. Tobias Barreto criticized the French positivism. The emphasis on German as opposed to the traditional association with France was arguably a symptom of a new balance of forces in Europe ${ }^{5}$. However, as for Brazil, Europe was still the reference, no matter whether the allusion was French or German.

The paper surveys some German authors whose books were in 'Tobias Barreto' s personal library. His

Rechtsgeschichte Europas in globalhistoricher perspective. In: RECHTSGESCHICHTE legal history rg 20. 2012. Available: <http:/ / dx.doi.org/10.12946/rg20/018-071>. Accessed on: Dec, 10 ${ }^{\text {th }}, 2014$, p. 18-71.

2 See, COING, Helmut. Das recht als element der europäischen kultur. Heildelberg: Verlag Lambert Schneider, 1983. This tradition somewhat has been built since the late middle ages. See, BELLOMO, Manlio. L'Europa del diritto comune. Roma: I Cigno Galileo Galilei Edizioni di Arte e Scienza, 1994. For some general terms in the European legal culture context see HELLERINGER, Geneviève; PURNHAGEN, Kai. Towards a european legal culture. Baden-Baden: Nomos, 2014.

3 As for this concept, STEIN, Peter; SHAND, John. Legal values in western society. Edinburgh: Edinburgh University Press, 1974.

4 See, GROSSI, Paolo. L'Europa del diritto. Roma; Bari: Laterza, 2007. p. 4.

5 In 1870, a new European order was fixed. The triumph of Germany in Sedan may had some cultural outcomes, which points to the idea that cultural values are somewhat a mirror of political power. This account can be tested in language studies. The role of Greek during the Antiquity, the role of Latin during the Late Antiquity as well as in the Middle Ages, the role French during the XVIII th century and the presence of English language as a lingua franca since the XIX th century are instances of this account. books were sold to the Law School in which he studied and worked, due to the effort of Clovis Bevilacqua, a Brazilian legal scholar who was of a paramount importance in the beginning of the twentieth century, allegedly one of the main authors of the Brazilian Civil Code.

As for the present discussion, there is a riddle, which the transposition theory has to consider, for authors could be lately forgotten in the original cultural context they lived. How a South American counterpart chose European authors in the nineteenth century? How ideas and judicial concepts were transposed from one place into another? How several German authors are related to Tobias Barreto? For what reason and in what context Tobias Barreto quoted them? Those are some issues raised in the paper.

\section{Tobias Barreto and his German MOTIVATIONS}

Tobias Barreto (1839-1889) was a professor, lawyer, journalist and poet. He is a founder of a school of jurisprudence that Brazilian scholars have termed the School of Recife. This designation is due to the city where he taught Law in the 1880's. There was a law school, established by an imperial order in $1827^{6}$, traditional and important, up to now.

As mentioned, Tobias Barreto was also a poet. He framed his verses in the canon of the Brazilian romanticism. The struggle against slavery was an enduring subject that fueled the poetry he composed. As a publicist, Tobias Barreto had extensively published in local newspapers. An aggressive polemist, Tobias Barreto had cultivated many foes and sectaries, as well as many supporters.

Tobias Barreto was fully studied by Mario Losano, an Italian scholar, who emphasized the German influences on Barreto's thoughts. Losano had carefully examined the German books that belonged to Tobias Barreto's personal library, on a famous field research he completed in the city of Recife ${ }^{7}$. It is significant to register that Tobias Barreto

6 Only in 1827 there were founded Law schools in Brazil. They were located in São Paulo (down South) and in Olinda (in the Northeastern part of Brazil). The Olinda school was shortly after transfered to Recife.

7 LOSANO, Mario. Tobias Barreto, um giurista tropicale: Tobias Barreto fra Brasile reale e Germania ideale. Roma; Bari: Laterza, 2000. 
is one of the five Brazilians summarized on the famous Michael Stolleis' Lexicon'. He has also a short biography on a Spanish lexicon entitled Juristas Universales?. He is likewise studied on the notorious Spanish Dicionario critico de juristas espanoles, portugueses y latinoamericanos ${ }^{10}$, in which the authors stressed the influence of Ernst Haeckel and Ludwig Büchner upon his own philosophy.

The paper addresses the German influence in the Brazilian legal thought, which resulted — among others — in the first Brazilian Civil Code, sanctioned in 1916, in the aftermath of a long struggle that occurred in the Brazilian Congress ${ }^{11}$. The German Civil Code-Bürgerliches Gesetzbuch-BGB, due to the prestige of German in the realm of Private Law, had a great ascendency upon the Brazilian Code of Private Law. In addition, some German authors anterior to the BGB, like Gustav Hugo, Friedrich von Savigny and Rudolf von Jhering were telling and effective in the context of Brazilian legal thought.

This prestige was somewhat due to the approach of a group of Brazilian scholars towards the German legal thought, in which Brazil underwent the discussion on them fashionable topics, as Naturrecht, Positivismus, historiche Schule and Pandektenrecht, to borrow a fragment of Uwe Wesel's monumental work ${ }^{12}$. The outcome consisted in a strong resistance to French influence, which was prevailing up to them. The Brazilian tendency to follow the German private legal framework, as opposed to the previous trend to follow the French legal outlook, was a deployment of a set of ideas condensed in the program of scholars of the mentioned School of Recife. For instance, the main author of the Brazilian Civil Code, Clovis Beviláqua, was himself a germanist and a learner of Tobias Barreto. They had a long lasting friendship.

Tobias Barreto was a mulatto from a poor background; his father was a civil servant with minor du-

8 STOLLEIS, Michael (Org.). Juristen- ein biographisches lexicon von der antike bis zum 20 jahrbundert. München: Beck, 2001. p. 65. The other ones are: Teixeira de Freitas (p. 85), Clóvis Beviláqua (p. 64), Pontes de Miranda (p. 509) and Rui Barbosa (p. 63).

9 DOMINGO, Rafael (Org.). Juristas universales. Barcelona: Marcial Pons, 2004. p. 466. There is only another Brazilian mentioned in this publication: Clóvis Beviláqua (p. 728).

10 PELÁEZ, Manuel J. (Ed.). Dicionario crítico de juristas españoles, portugueses y latinoamericanos. Zaragoza y Barcelona: Cometa, 2005. p. 135.

11 See RODRIGUES JÚNIOR, Otavio Luís. A Influência do BGB e da doutrina alemã no direito civil brasileiro do século XX. São Paulo: Revista dos Tribunais, 2013. v. 938. p. 79-155.

12 WESEL, Uwe. Geschichte des rechts in europa-von den griechen bis zum vertrag von lissabon. München: Verlag C. H. Beck, 2010. p. 509-512. ties, responsibilities and income. Barreto attended Law School in Recife and afterwards learned German on his own. In 1870, he bought a German dictionary and a German grammar. He ordered his bookseller the very first book he read in German: Einleitung in die Geschichte des Volkes Israels, penned by Heinrich Ewald ${ }^{13}$, published in Gottingen, in $1864^{14}$. This very book can be seen today in the law school library where Barreto had taught ${ }^{15}$. The volume is a relic.

The recommendation of the first German book Tobias Barreto had bought is a relevant hint for the present argument; for we have no clues of how he could have chosen the German books he bought. A catalog in the hands of his bookseller could have inspired titles that he had chosen. In addition, the amount of time demanded until the arrival of the books, prices, as well as references collected in other readings, are facts that suggest countless circumstances towards which one can only digress.

Tobias Barreto rejected Auguste Comte and the French positivist tradition ${ }^{16}$. As he had once affirmed, "the German thinkers, in almost all realms of wisdom, are, at least, ten years ahead of the French"17. He was a germanist whose ideas have transformed the way some Brazilian scholars understood law. Tobias Barreto comprehended law not as an heir of the heavens, but as an historical phenomenon. He had many followers such as Silvio Romero, Pontes de Miranda, Hermes Lima and Miguel Reale, who are among the most influential Brazilian philosophers of law.

Tobias Barreto taught Jurisprudence in Recife from 1882 to almost the year of his death. He had an enormous prestige among his students. As for his tendency

13 Heinrich Ewald (1803-1875) was educated in Göttingen, were he studied Theology and Ancient Languages.

14 The sample on Tobias Barretos' library is EWALD, Heinrich. Einleitung in die geschichte des volkes Israels. Goettingen: Dietrichsche Buchlandlung, 1864. The first edition of this book was published in 1843.

15 A sample of this book is among the collection mentioned on a catalog of a exposition of Tobias Barreto's books in the 170 th year of his birth. Catálogo da Mostra Bibliográfica da Exposição Tobias Barreto: as marcas de um homem (170 anos de nascimento- 1839-1889). Recife: Faculdade de Direito, 2009.

16 See, PAIM, Antonio. A filosofia da escola do Recife. Rio de Janeiro: Saga, 1966.

17 BARRETO, Tobias. Estudos de direito. Campinas: Bookseller, 2000. p. 19. Originally in Portuguese: "Os pensadores alemães, em quase todos os dominios da inteligência, andam dez anos, pelo menos, adiante dos franceses". 
towards German ideas, it is illuminating to consider the fact that he wrote three monographs in the German language. Namely, Brasilien wie es ist in literarischer Hinsicht betrachtet (1876), Ein offener Brief an die deutsche Presse (1878) and Rechtsleben und Rechtstudium in Brasilien (1880); this last one is by all accounts lost. In the 1870's, when living in the hinterlands of the state of Pernambuco, Tobias Barreto published a few issues of a newspaper written in German, Deustscher Kämpfer. Probably nobody but him had effectively read the mentioned magazine.

In the face of 'Tobias Barreto' writings one can speculate about the sources that fostered his philogermanism. He mentioned a German magazine, named The Prussian Annals, in an emblematic excerpt. This journal circulated the ideas and authors Tobias Barreto frequently had quoted. In this very passage, Tobias Barreto notices this mentioned magazine to an opponent, in a debate, which to some extent suggests that many writers quoted by Barreto were not firsthand read. According to Barreto:

The Prussian Annals is a name of scientific
magazine which is monthly published in Berlin,
since 1857, reaching two volumes of circa 500 do
600 pages, which amounts to 62 volumes this year.
Its director and main editor is the great scholar
Treitschke, including names are Michael Bernays,
Hermann Grimm, Heinrich Honberger, Theodor
Mommsen, Rudolf Geneist and many others $[\ldots]^{18}$.

Many a Tobias Barreto's essays related to German's thinkers were published on a single book named German Studies (in Portuguese: Estudos Alemães) ${ }^{19}$, in which it is quite extraordinary the influence he had from German scholars such as Eduard von Hartmann, Franz von Holtzendorff, Rudolf von Jhering and Immanuel Kant, among many others. Tobias Barreto was also the first Brazilian academic to quote Karl Marx ${ }^{20}$.

18 BARRETO, Tobias. Estudos de direito. Rio de Janeiro, Sergipe: J. E. Salomon, Editora Diário Oficial, 2012. v. 1. p. 255. In Portuguese: “[...] Anais Prussianos é o nome de uma revista científica e literária que se publica em Berlim, desde 1857, em fascículos mensais, formando anualmente dois volumes de 500 a 600 páginas cada um e já contando, por conseguinte, no ano que corre, 62 volumes. Tem como diretor e principal redator o grande Treitschke, professor universitário, e nela tem nomes como os de Michael Bernays, Hermann Grimm, Henrique Honberger, Theodor Mommsen, Rudolf Gneist e muitos outros [...]".

19 BARRETO, Tobias. Estudos alemães. Rio de Janeiro; Aracaju: Record; Secretaria de Cultura e Meio Ambiente, 1991.

20 See CHACON, Vamireh. Da escola do Recife ao código civil. Rio de Janeiro: Organizações Simões, 1969.

\section{Tobias Barreto's German library}

Tobias Barreto's personal library was sold right after his death to the Law School in which he had studied and taught. There were 114 German books, especially in the fields of Jurisprudence, Constitutional Law, Administrative Law, Roman Law, Religion and Social Sciences in general. To quote a few, in the realm of Jurisprudence, there were books from Rudolf von Jhering ${ }^{21}$ and Salomon Stricker ${ }^{22}$. As for Administrative Law the library had a book written by Rudolf von Gneist ${ }^{23}$. In the ground of Constitutional Law he had books written by Joseph Sötvös ${ }^{24}$, Leonhard Freund ${ }^{25}$, Julius Froebel ${ }^{26}$, Franz von Holtzendorff ${ }^{27}$, Eugen $\mathrm{Huhn}^{28}$, Adolf Samuely ${ }^{29}$ and again Rudolf von Gneist ${ }^{30}$.

The notorious book of Roman Law authored by Theodor Mommsen ${ }^{31}$ was among the ones owned by Tobias Barreto. There were also books on Criminal Law, penned by Albert Friedrich Berner ${ }^{32}$, Emil Kraeplin $^{33}$, Heinrich Lammasch ${ }^{34}$ and William Lagenbeck ${ }^{35}$. This personal library gives us a clue of the sources that inspired him. One does not know why he had chosen the books he had, but one can trace the outcome of its motivation by way of checking quotations and references throughout his writings.

21 JHERING, Rudolf Von. Der zweck im recht. Leipzig: Breitkopft \& Haertel, 1883.

22 STRICKER, Salomon. Physiologie des rechts. Wien: Teoplitz \& Deutick, 1884.

23 GNEIST, Rudolf. Self-government: communalverfassung und verwaltungs-gerichte. Berlin: Springer, 1871.

24 STÖVÖS, Joseph. Der einfluss der herrschenden ideen des 19 jabrbunderts auf den staat. Wien: Jasper, Hügel \& Manz, 1851.

25 FREUND, Leonhard. Thaten und namen: forschungen ueber staat und gesellschaft mit besonderer ruecksicht auf lorenz stein und Ruldolf Gneist. Berlin: F. Henschel, 1871.

26 FRÖBEL, Julius. Die gesichtspunkte und aufgaben der politik. Leipzig: Duncker \& Humboldt, 1878.

27 HOLTZENDORFF, Franz Von. Materialen der deutschen reichsverfasssung. Berlin: C. Habel, 1873.

28 HUHN, Eugen. Politik. Leipzig: Wilhelm Grunow, 1865.

29 SAMUELY, Adolf. Das prinzip der ministerverantwortlichkeit in der constitutionellen monarchie. Berlin: J. Springer, 1869.

30 GNEIST, Rudolf. Die preussische kreis-ordnung. Berlin: J. Springer, 1870. 31 MOMMSEN, Theodor. Roemisches staatsrecht. Leipzig: Hirzel, 1876.

32 BERNER, Albert Friedrich. Grundsaetze des preussichen Strafrechts. Leipzig: Verlag von Berhnhard Tauchnilz, 1861.

33 KRAEPLIN, Emil. Die abschaffung des strafnaßes. Stuttgart: F. Enke, 1880.

34 LAMMASCH, Heinrich. Das moment objectiver gefaehrlichheit im begriffe des verbrechensersuches. Wien: Alfred Hoelder, 1879.

35 LAGENBECK, Whillelm. Die Lehre Von der Teilnahme am verbrechen. Jena: Mauke, 1868. 
In Portuguese, there is a remarkable bibliography concerning Tobias Barreto ${ }^{36}$, in which his concern towards German culture has always been stressed. Tobias Barreto had a great responsibility vis-à-vis the reception of Rudolf von Jhering in Latin America. He was a resilient critic of Natural Law, which he understood as an out to date conception of legal affairs. He denied the possibility of a sociology of law. In that sense, his ideas were totally opposed to Augusto Comte's positivism ${ }^{37}$.

The core of Tobias Barreto's thought was essentially German. The authors he quoted were German jurists, philosophers and social scientists. Greatly influenced by Rudolf von Jhering, Tobias Barreto was a forerunner of the Brazilian culturalism, that is, a legal philosophy that defended that law is an institutional arrangement created by human beings, reflecting the cultural milieu of a given society. Law is not a son of the heavens, it is an artefact of human culture; a motto that Tobias Barreto had continuously mentioned. Tobias Barreto understood law as an historical object; in that sense, he is the Brazilian upholder of the German Historische Rechtsschule, which is mainly attached to Friedrich Karl von Savigny ${ }^{38}$, and, however in a different sense, to Rudolf

36 Among others: AMADO, Gilberto. Tobias Barreto. Rio de Janeiro: Ariel, 1934. BARRETO, Luiz Antônio. Tobias Barreto, a abolição da escravatura e a organização da sociedade. Sociedade. Recife: Editorial de Sergipe, 1988. BEVILACQUA, Clóvis. Tobias Barreto. In: JURISTAS Filósofos. Salvador: Livraria Magalhães, 1897. p. 75-95. CAMPOS, Virgílio. Tobias Barreto e a revolução jurídica alemã: a influência de Von Jhering no pensamento tobiático. Recife: [s. n.], 1988. CORTES, Paulo Campos. Tobias Barreto: antologia de idéia, uma revelação. Rio de Janeiro: Radial, 1974. CORTES, Paulo Campos. A concepção filosófica de Tobias Barreto. Rio de Janeiro: [s. n.], 1980. DANTAS, Paulo. Tobias Barreto. 2. ed. São Paulo: 1952. FERREIRA, Luis Pinto. Tobias Barreto e a nova escola de Recife. Recife: Imprensa Industrial, 1953. GAMA, Affonso Dionyzio. Tobias Barreto. São Paulo: Monteiro Lobato, 1925. LIMA, Hermes. O pensamento vivo de Tobias Barreto. São Paulo: Martins, 1943. LIRA, Roberto. Tobias Barreto, o homem-pêndulo. Rio de Janeiro: Companhia Editora Nacional, 1937. MONT'ALEGRE, Omer. Tobias Barreto. Rio de Janeiro: Vecchi, 1939. MORAES FILHO, Evaristo de. Medo à utopia: o pensamento social de Tobias Barreto e Silvio Romero. Brasília, Rio de Janeiro: Nova Fronteira; INL, 1985. PEREIRA, Virgílio de Sá. Tobias Barreto. Rio de Janeiro: Revistas dos Tribunais, 1917. ROMERO, Nelson. Tobias Barreto. Rio de Janeiro: Globo, 1943.

37 As for this synthesis, PELÉZ, Manuel J.; BRÁS TEIXEIRA, Antonio. Tobias Barreto. In: DOMINGO, Rafael (Org.). Juristas universales. Madrid, Barcelona: Marcial Pons, 2004. p. 465-466.

38 SAVIGNY, Freidrich Karl Von. De la vocación de nuestro siglo para la legislacion y la ciencia del derecho. Buenos Aires: Arengreen, 1946. Also, as for the debate Savigny v. Thibaut, Marini, Giuliano, MARINI, Giuliano. La polemica sulla codificazione. Napoli: Edizioni Scientifiche Italiane, 1982. BECCHI, Paolo. Ideologie dela codificazione in Germania. Genova: Companhia del Librai, 1999. CONTRERAS von Jhering ${ }^{39}$. Tobias Barreto was fascinated by a celebrated text from Rudolf von Jhering, Die Jüspruden₹ des täglichen Lebens ${ }^{40}$, a simple book that analyses facts of daily life in the perspective of its legal consequences ${ }^{41}$.

Among the variety of authors quoted by Tobias Barreto some are forgotten today. In the realm of law, except for Jhering, most of them were not even rendered into Portuguese. The contemporary reader has a difficult task when trying to comprehend the sources that nourished Tobias Barreto ideas and books.

In the context of 1860 's Germany, who were the authors that he had studied and quoted? How was the German cultural and legal environment in the 1870's and in the 1880 's ${ }^{42}$ ? What is the influence of the $\mathrm{Kul}$ turkampf and the Bismarckian era upon Tobias Barreto? How was the legal environment in which had written and taught Rudolf von Gneist, who had studied under Savigny? According to Michael Stolleis,

Rudolf von Gneist was a parliamentarian, university
teacher, founding father of the German Jurists'
Colloquy, founder of the Union for Defense against
anti-Semitism, advisor to the foreigner office, privy
councilor, Wirkilich Geheimer Oberjustitzrat (with
the right to title 'Excellenz') [...] a man raised to the
status of nobility with right to bequeath his title,
he held honorary doctorates from the universities
of Edinburgh, Bologna, Oxford, and Dublin $[\ldots]^{43}$.

One also gathers information about the authors that governed Tobias Barreto's thought in some of Michael Stolleis' books, especially Public Law in Germany-18001914, as well as in Francisco Sosa Wagner's study on the German masters of Public Law ${ }^{44}$. In order to shed

PELÁEZ, Francisco J. Savigny y el historicismo jurídico. Madrid: Tecnos, 2005. JOUANJAN, Olivier (Org). L'esprit de l'école historique du droit. Strasbourg: Presses Universitaires de Strasbourg, 2004. LABOULAYE, Édouard. Essai sur la vie et les doctrines de Frédéric Charles de Savigny. Paris: A. Durand, 1842.

39 KLEMAN, Bernd. Rudolf Von Jhering und die historische rechtschule. Frankfurt am Main; Bern; New York; Paris: Verlag Peter Lang, 1989. 40 In the Max-Planck Institute für Europäische Rechtgeschichte there is a sample of this famous book: JHERING, Rudolf Von. Die Jurisprudenz des täglichen lebens. Iena: Verlag Von Gustav Fischer, 1927. 41 BARRETO, Tobias. Estudos de direito. Rio de Janeiro, Sergipe: J. E. Salomon, Editora Diário Oficial, 2012. v. 1. p. 72-82.

42 Among a whole variety of authors in this subject, see, for the legal environment, FEHR, Hans. Deutsche rechtsgeschichte. Berlin: Walter de Gruyter \& CO, 1962. p. 283-294. Also, HOKE, Rudolf. Österreichische und deutsche rechts-geschichte. Wien, Köln, Weimar: Böhlau Verlag, 1992. p. 419-438.

43 STOLLEIS, Michael. Public law in Germany, 1800-1914. New York: Oxford, 2001. p. 379.

44 SOSA WAGNER, Francisco. Maestros alemanes del derecho público. Barcelona: Marcial Pons, 2005. 
light on Tobias Barreto' main ideas, one must study the bibliographical sources that explore the background of German private and public law in the 1860 's ${ }^{45}$. In this framework, one finds the cultural background that influenced Tobias Barreto, particularly the idea of law as a human artefact and not as metaphysical value to be pursued.

Again in the matter of the German authors who influenced Barreto, for instance, in Michael Stolleis' book there are excerpts regarding Rudolf von Jhering ${ }^{46}$, Rudolf von Gneist ${ }^{47}$, Franz von Holtzendorff ${ }^{48}$, Adolf Samuely $^{49}$, Theodor Mommsen ${ }^{50}$ and Heinrich Lammasch $^{51}$. Francisco Sosa Wagner mentioned Theodor Mommsen $^{52}$, Heinrich Lammasch ${ }^{53}$, Franz von Holtzendorff ${ }^{54}$ and Rudolf Gneist ${ }^{55}$.

The topic raises some interesting questions. Who are all the German authors that Barreto had read? Does the simple fact that the contemporary literature hardly mentioned some of them is a suggestion that they are worthless, at least today? Is it significant that some of them did not have historical recognition? On the other hand, does one run the risk of being unkind to Tobias Barretos's sources, since one has today the benefit of the hindsight? In addition, which is the most important question, to what a magnitude has Tobias Barreto contributed to the spreading of German thought in Brazilian academy?

45 See, EISENHARDT, Ulrich. Deutsche rechtsgeschichte. München: Verlag C. H. Beck, 1994. p. 367-390.

46 STOLLEIS, Michael. Public law in Germany, 1800-1914. New York: Oxford, 2001. p. 260; 310; 316; 357; 420; 429; 436.

47 STOLLEIS, Michael. Public law in Germany, 1800-1914. New York: Oxford, 2001. p. 207; 217; 240; 257; 281; 329; 339; 361; $377-$ 9; 396.

48 STOLLEIS, Michael. Public law in Germany, 1800-1914. New York: Oxford, 2001. p. 357; 365; 372; 410; 454.

49 STOLLEIS, Michael. Public law in Germany, 1800-1914. New York: Oxford, 2001. p. 87.

50 STOLLEIS, Michael. Public law in Germany, 1800-1914. New York: Oxford, 2001. p. 133; 287; 261.

51 STOLLEIS, Michael. Public law in Germany, 1800-1914. New York: Oxford, 2001. p. 304.

52 SOSA WAGNER, Francisco. Maestros alemanes del derecho público. Barcelona: Marcial Pons, 2005. p. 84; 115; 118; 119; 149; 189; 227; 427.

53 SOSA WAGNER, Francisco. Maestros alemanes del derecho público. Barcelona: Marcial Pons, 2005. p. 179; 386-388.

54 SOSA WAGNER, Francisco. Maestros alemanes del derecho público. Barcelona: Marcial Pons, 2005. p. 208.

55 SOSA WAGNER, Francisco. Maestros alemanes del derecho público. Barcelona: Marcial Pons, 2005. p. 84; 89; 131; 166; 177; 208; 421; 426; 520.
As for the authors quoted by Tobias Barreto it is true that Stolleis and Sosa Wagner mentioned only some of them, which is rather noteworthy, for the historical reception of the authors that Tobias Barreto had studied may confirm how unforeseeable the transportation of institutional arrangements and ideas might be. This is the point the paper tries to explore most.

\section{Exploring Tobias Barreto's German AUTHORS}

The main burden that lays ahead is to explore the German authors who had some level of prominence on Tobias Barreto's thought, thus enhancing some comprehension of the Brazilian history of ideas, as well as discussing the reception and translation of cultural values. It is indispensable to explore why and in what specific context had Tobias Barreto quoted the German authors he had read, who were unfamiliar to most of his colleagues.

One must identify his personal library, so in order to map Tobias Barreto's German books there were checked the following sources. First, the presence (or not) of Tobias Barreto's authors on a publication named Deutsche Biographie - Onlinefassung, which covers the most prominent German names related to politics, economics, law, social sciences and $\mathrm{art}^{56}$. Most of the authors quoted by Tobias Barreto are studied (some at length) in the above mentioned publication.

Secondly, it must be checked the presence (or not) of Tobias Barreto's authors in the Deutsche Biographische Enzylklopädie $e^{57}$. This publication disclose some level of relevance of those who were chosen. Thirdly, a check on the Katalog der Bibliotek des Deutschen Reichstages, published in Berlin, in 1882. It allows one to grasp whose authors had some relevance at the time when Tobias Barreto had bought his German books.

Then, it is necessary a look into the Deutsche und Europäische Juristen aus Neun Jahrbunderten ${ }^{58}$. Follows a check on a Spanish Biographical Dictionary, Juristas Universa-

56 C.f. <http://www.deutsche-biographie.de/>.

57 KILLY, Walter. Deustsche biographische ensylelopädie. München; New Providence: K. G. Saur, 1995.

58 KLEINMEYER, Gerd; SCHRÖDER, Jan (Hrsg.). Deutsche und europäische juristen aus neun jabrbunderten. Heilderberg: C. F. Müller Verlag, 2008. 
$\operatorname{les}^{59}$. In the next step, there is a check on some old books at the Max-Planck Institut für Europäische Rechtsgeschiche library, as well as in biographies or references related to the authors here considered. All condensed, follows some information.

\section{AN ACCOUNT OF SOME AUTHORS FOUND ON Tobias Barreto's German library}

Rudolf von Jhering (1818-1892) is the most acclaimed author quoted by Tobias Barreto ${ }^{60}$. One of the leading German Legal Scholars of his lifetime, Jhering has an impressive biographical canvas in the mentioned Deutsche Biographische Enzyklopädie ${ }^{61}$. Jhering is also portrayed by Deutsche Biographie ${ }^{62}$, in which two long articles cover his life, ideas and work. In 1882, the Katalog der Bibliotek des Deutschen Reichstages registered many of his books ${ }^{63}$. He also had his profile in the Juristas Universales ${ }^{64}$, as well as in Michael Stolleis's Lexicon $^{65}$. No doubts he was very important.

In a syllabus that Tobias Barreto had prepared for his students is very clear the influence he received from Rudolf von Jhering ${ }^{66}$. Barreto intended to discuss the impact of Darwinism in law. With this purpose, he advocated some discussion on Jhering ideas. Tobias planned to study Law as power, that is, he shielded the study of Law in its physiological and morphological context ${ }^{67}$. The German ideas on Tobias Barreto had approached

59 DOMINGO, Rafael (Org.). Juristas universales. Barcelona: Marcial Pons, 2004.

60 For a complete bibliography regarding Rudolf Von Jehring, see LOSANO, Mario. Bibliografia di Rudolf Von Jhering. Torino: Giulio Einaudi, 1968.

61 Che Biographische Enzyklopädie. v. 5. p. 245.

62 HOLLERBACH, Alexander; IHERING, Rudolf Von. In: NEUE Deutsche Biographie 10, 1974. Available: <http://www. deutsche-biographie.de/pnd118555367.html>. p. 123-124. MITTEIS, L.; IHERING, Rudolf. In: ALLGEMEINE Deutsche Biographie, 1905. Available: <http://www.deutsche-biographie.de/ pnd118555367.html>. Accessed on: Dec, 10 ${ }^{\text {th }}, 2014$. p. 1-18.

63 Among the entries: Geist des Römischen Rechts (p. 379), Kampf und Recht (p. 373) and Jurisprudenz des täglichen Lebens (p. 371).

64 DOMINGO, Rafael (Org.). Juristas universales. Barcelona: Marcial Pons, 2004. p. 308.

65 STOLLEIS, Michael (Org.). Juristen-ein biographisches lexicon von der antike bis zum 20 jabrbundert. München: Beck, 2001. p. 334.

66 BARRETO, Tobias. Estudos de direito. Rio de Janeiro; Sergipe: J. E. Salomon; Editora Diário Oficial, 2012. v. 1 p. 65.

67 BARRETO, Tobias. Estudos de direito. Rio de Janeiro; Sergipe: J. E. Salomon; Editora Diário Oficial, 2012. v. 1. p. 65.
Brazilian scholars to Darwin and evolutionism, nonetheless through Jhering ${ }^{68}$.

On a thesis submitted to Recife Law School Tobias Barreto rejected the metaphysical idea of Law, insisting that Law also depended upon the laws of natural selection, in the context of the struggle for $\operatorname{life}^{69}$, which discloses the impact he received from Jhering. Tobias Barreto understood Law not as a soon of heavens, but simply as an historical phenomenon, a cultural device of humanity ${ }^{70}$. In this sense, Tobias Barreto had approached Law to the idea of power, that is, the power that does not overcome power does not become Law, for Law is power, which destroyed power itself ${ }^{71}$.

Tobias Barreto had studied a famous conference given by Rudolf von Jhering, published as The Struggle for Law-Der Kampf um's Recht ${ }^{72}$, which he mentioned on a somewhat sarcastic way, for his Brazilian colleagues would have known the text on its French version:

The speech given by the conspicuous scholar in March of 1872, before he went to Vienna, to Gottingen, to the Viennese Legal Society, and under a title, which by itself worth a discovery. "The Struggle for Law" (Der Kampf ums Recht) was soon after published translated into French; and, in this is way dressed, the book can reach us ${ }^{73}$.

In fact, Rudolf von Jhering was the German author who most influenced Tobias Barreto. The Brazilian scholar commented devotedly Jurisprudence of Daily Life, a famous book by Jhering ${ }^{74}$. There is a notice that Tobias Barreto and his colleague Silvio Romero had sent a

68 REALE, Miguel. Estudos de filosofia brasileira. Lisboa: Guimarães Editores, 1994. p. 115. Also, REALE, Miguel. Figuras da inteligência brasileira. São Paulo: Siciliano, 1994. p. 54.

69 BARRETO, Tobias. Estudos de direito. Rio de Janeiro; Sergipe: J. E. Salomon; Editora Diário Oficial, 2012. v. 1. p. 56.

70 BARRETO, Tobias. Estudos de direito. Rio de Janeiro; Sergipe: J. E. Salomon; Editora Diário Oficial, 2012. v. 1. p. 52.

71 BARRETO, Tobias. Estudos de direito. Rio de Janeiro; Sergipe: J. E. Salomon; Editora Diário Oficial, 2012. v. 1. p. 52. Original in Portuguese: "A força que não vence a força não se faz direito; o direito é a força, que matou a própria força".

72 Among several translations into Portuguese, the most known is BASTOS, José Tavares. A luta pelo direito. Porto: Livraria Chardon, 1810.

73 BARRETO, Tobias. Estudos de direito. Rio de Janeiro; Sergipe: J. E. Salomon; Editora Diário Oficial, 2012. v. 1. p. 73. In Portuguese: “O discurso que fizera o ilustre sábio em março de 1872, antes de sua partida de Viena para Gottingen, na Sociedade Jurídica Vienense, e sob o título, que vale por si só uma descoberta. 'A Luta pelo Direito’ (Der Kampf ums Recht), foi logo depois de sua publicação vertido em francês; e, nesse trajo, pode também chegar até nós".

74 BARRETO, Tobias. Estudos de direito. Rio de Janeiro; Sergipe: J. E. Salomon; Editora Diário Oficial, 2012. v. 1. p.73-74. 
letter to Rudolf von Jhering, inviting him for a visit to the Recife Law School ${ }^{75}$; Jhering had never come to Brazil, nor we have any information concerning Jhering's answer to this invitation.

Rudolf Gneist (1816-1895) is the second most known of the authors Tobias Barreto had in his library. Gneist has an imposing biographical summary in the Deutsche Biographische Ensyklopädie ${ }^{76}$, in the Juristas Universales $^{77}$, as well as in Michael Stolleis' Lexicon ${ }^{78}$. Rudolf Gneist was the typical political jurist of the Bismarckian era (Ein politischer Jurist in der Bismarckzeit), as remarked by Eric J. Hahn, one of his biographers, in a dissertation defended at Yale University in $1971^{79}$.

Rudolf Gneist attended Law School in Berlin. He was a student of Friederich von Savigny ${ }^{80}$, from whom he gained an undying relation to Roman Law, which he subsequently taught at his alma mater. An admirer of the English Constitution and British liberalism, Gneist had fought the Prussian autocracy. He had cooperated with Japan in the conception of a Japanese Constitution, right in the blossom of the Meiji Era, in which the Japanese stubbornly tried do copy Western patterns ${ }^{81}$. Well aware of the necessary bridge amid theory and practice, Gneist had proceeded in the Prussian Court as a "Hilfesarbeiter" cription of Gneist, here quoted, as follows, on a free version of my responsibility:

Heinrich Rudolf Hermann Friedrich von Gneist, member of the German Reichtag and Law School Professor at the University of Berlin, is counted among the most important juspublicists of our times. In his country, where one has all the major names of all cultural genders and where many a times on a unique spot one has all groups of eagles, Gneist is known, without any doubt, as a most important expert on English Public Law [...] Gneist's books,

75 BARRETO, Tobias. Estudos de direito. Rio de Janeiro; Sergipe: J. E. Salomon; Editora Diário Oficial, 2012. v. 1. p. 73.

76 DEUSTSCHE Biographische Enzyklopädie. V. 3. p. 44.

77 DOMINGO, Rafael (Org.). Juristas universales. Barcelona: Marcial Pons, 2004. p. 281.

78 STOLLEIS, Michael (Org.). Juristen- ein biographisches lexicon von der antike bis zum 20 jabrbundert. München: Beck, 2001. p. 246.

79 HAHN, Ericj J. Rudolf von Gneist: 1816-1895, ein politischer jurist in der bismarckzeit. Frankfurt: Vittorio Klostermann, 1995.

80 HAHN, Ericj J. Rudolf von Gneist: 1816-1895, ein politischer jurist in der bismarckzeit. Frankfurt: Vittorio Klostermann, 1995. p. 3. 81 HAHN, Ericj J. Rudolf von Gneist: 1816-1895, ein politischer jurist in der bismarckzeit. Frankfurt: Vittorio Klostermann, 1995. p. 233.

82 ESSER, Dirk. Gneist als qivilrechtslebrer: die pandektenvorlesung des wintersemesters: 1854-55. Paderborn; München; Wien; Zurich: Ferdinand Schöningh, 2004. p. 16. consecrated to the study of this subject, almost reduce to inutility the books of English authors, overcoming it by the profundity of its analyses and the extension of its insights. In order to make it plausible trying to proof its truth, it is enough to warn that all the English publicists are partisan, prismatic, reflecting the political party they belong to $[\ldots]$ One understands that the wise Professor of Berlin could well avoid such a problem, which is not too small. He would be himself an Excellency, when to its qualities one could not combine, as it is combined in superior ranking, the scientific geniality of a personal research, fecund and indefatigable, amidst such an immense scholarship. ${ }^{83}$

In the Max-Planck Institut für Europäische Rechtsgeschiche library there is a sample of a Gneist's book on the English Constitution ${ }^{84}$. In Brazil, this book raised an issue between Tobias Barreto and Jose Higino Duarte Pereira, an endless debate unfolded on local newspapers. The quarrel was due to the translation of a German word, "Obrigkeit". During the argument, Barreto tried to show himself as the only one in Recife who was able of reading and translating German. One can admit that the knowledge of the German language was a rhetorical strategy used by Tobias Barreto in order to weaken his opponents. In a certain way, this approach is still effective in today's Brazil.

In the mentioned dispute, Barreto had even challenged his opponent to bring the book penned by Gneist in which there was the quotation that he had repudiated. Next day, in the same newspaper, Jose Higino had answered that he actually had a book from Gneist, albeit his ideas were borrowed from another German author, Oscar Glüth ${ }^{85}$.

83 BARRETO, Tobias. Estudos de direito. Rio de Janeiro; Sergipe: J. E. Salomon; Editora Diário Oficial, 2012. v. 1. p. 231. In: Portuguese: "Henrique Rodolfo Frederico Gneist, membro do Reichtag alemão e professor da Faculdade Jurídica, na Universidade de Ber$\mathrm{lim}$, é contado entre os maiores publicistas da época atual. No seu país, onde aliás se agrupam grandezas de todo o gênero e muitas vezes numa só colina aninha-se um bando de águias, passa ele sem contestação pelo mais vasto conhecedor do direito público inglês [...] As obras de Gneist, consagradas ao estudo dessa matéria, quase tornam inúteis as dos próprios escritores da Grã-Bretanha, sobrepujando-as em profundeza de análise e extensão de vistas. Para tornar concebível e evidenciar essa verdade, basta advertir que os publicistas ingleses são todos tendenciosos, prismáticos, refletores de um partido a que pertencem [...] Compreende-se que o sábio professor de Berlim pôde bem evitar um tal defeito que não é pequeno. Já seria por si só uma excelência, quando a isto não se reunisse, como se reúne em grau superior, a genialidade científica de uma pesquisa própria, fecunda e infatigável, no meio de uma erudição pasmosa". 84 GNEIST, Rudolf. Selfgovernment-communalverfassung und verwaltusgnsgerichtr in England. Berlin: Verlag Von Julius Springer, 1871.

85 BARRETO, Tobias. Estudos de direito. Rio de Janeiro; Sergipe: J. 
Barreto also mentioned Gneist on a literary review of one of his books ${ }^{86}$. In another passage, discussing the political power of the Brazilian Emperor, Tobias Barreto had recurrently quoted Gneist, a propos of his commentaries on the English Constitutionalism. Clarifying the overwhelming moral and political significance that the British nurtured for opposing corruption Barreto had quoted Gneist strait from German language ${ }^{87}$. Likewise, Barreto had cited Gneist in order to argue that Brazil had solely copied English institutions, doing so inappropriately ${ }^{88}$. After all, concluded Barreto, the Brazilian social organism was not the English one ${ }^{89}$.

Tobias Barreto had studied English Constitutional Law in Gneist's books. He was not acquainted to English authors, which is quite clear while one reads the commentaries that Barreto had published in the issue of British ministries' political responsibilities ${ }^{90}$.

Follows Theodor Mommsen (1817-1903), whose main feature was the connection between Law and History ${ }^{91}$. Mommsen had a great influence on Savigny. In that sense, Mommsen is related to the inception of the Historical School of Jurisprudence. Mommsen studied and published in the realm of Roman Law. His Römisches Staatsrecht was studied and quoted at length by Tobias Barreto. Well familiar with Cicero, Cato, Caesar, Tacitus, Paulus, Varro, to name but a few ${ }^{92}$, Mommsen is the flawless illustration of a nineteenth century German scholar $^{93}$. In 1902, he was awarded the Nobel Prize for his literary skills. His life was devoted to learning. Culture and knowledge ${ }^{94}$, Wissenschaft and Bildung (notions

E. Salomon; Editora Diário Oficial, 2012. v. 1. p. 182-183.

86 BARRETO, Tobias. Estudos de direito. Rio de Janeiro; Sergipe: J. E. Salomon; Editora Diário Oficial, 2012. v. 1. p. 234.

87 BARRETO, Tobias. Estudos de direito. Rio de Janeiro; Sergipe: J. E. Salomon; Editora Diário Oficial, 2012. v. 1. p. 101-102.

88 BARRETO, Tobias. Estudos de direito. Rio de Janeiro; Sergipe: J. E. Salomon; Editora Diário Oficial, 2012. v. 1. p. 107.

89 BARRETO, Tobias. Estudos de direito. Rio de Janeiro; Sergipe: J. E. Salomon; Editora Diário Oficial, 2012. v. 1. p. 123.

90 BARRETO, Tobias. Estudos de direito. Rio de Janeiro; Sergipe: J. E. Salomon; Editora Diário Oficial, 2012. v. 1. p. 123.

91 DOMINGO, Rafael (Org.). Juristas universales. Barcelona: Marcial Pons, 2004.p. 298.

92 MOMMSEN, Theodor. Römisches strafrecht. Graz: Akademische Druck-U. Verlagsansalt, 1955.

93 For an study on the role of Theodor Mommsen on the contex of German XIX th century, see HEUSS, Alfred. Theodor Mommsen und ds 19. jabrbundert. Kiel: Ferdinand Hirt, 1956 especially pages 3357, Mommsen als Jurist.

94 See the memories of his daughter, MOMMSEN, Adelheid. Mein Vater: rinnerunger an Theodor Mommsen. München: Matthes \& Seitz Verlag, 1992. that are quite peculiar in German language ${ }^{95}$ ) are among the references inevitably related to his lifespan. He has a great deal of references on the mentioned Katalog der Bibliotek des Deutschen Reichstages ${ }^{96}$.

Tobias Barreto cited Mommsen several times. There is a footnote in which Barreto registered that he had studied Roman History on a Mommsen's book published in $1854^{97}$. Discussing some litigation issues, Barreto exemplified his point of view with a Roman Law lesson taken from Mommsen, in the realm of the relation between creditors and debtors ${ }^{98}$.

Commenting the fundaments of the right of punishing, Barreto had remarked, basing his opinion in Mommsen, some legacy of Roman Law, in whose historical context the offenses against an individual relied not in the community, but in the offended ${ }^{99}$. Commenting the Brazilian Criminal Imperial Code Tobias Barreto had quoted Mommsen in order to discuss the concept of crime itself ${ }^{100}$. Barreto was an expert in Latin, which also justifies the proximity of the Brazilian jurist with Mommsen: indeed; both were classicists.

Johann Kaspar Bluntschli (1808-1888), another author known by Barreto, was a student of Savigny in Berlin. Professor of Constitutional Law, he taught in Munich and later in Heildelberg. He dedicated part of his life do politics. Mario Losano refers to a Bluntschli's book that was at Tobias Barreto's library ${ }^{101}$. Bluntschli is an autor known outside Germany, for his books were translated into English ${ }^{102}$ and French ${ }^{103}$. Bluntschi is

95 See WATSON, Peter. The german genius-europe's third renaissance, the second scientific revolution and the twentieth century. London: Simon \& Schuster, 2010. p. 53.

96 Among them: Die Annexion Schleswig-Holsteins- ein Senschreiben an die Wählmänner der Stadt Halle (p. 68); Römische Froschungen (p. 774); Römische Geschichte (p. 773) and Römische Staatrecht (p. 49).

97 BARRETO, Tobias. Estudos de direito. Rio de Janeiro; Sergipe: J. E. Salomon; Editora Diário Oficial, 2012. v. 1. p. 168.

98 BARRETO, Tobias. Estudos de direito. Rio de Janeiro; Sergipe: J. E. Salomon; Editora Diário Oficial, 2012. v. 1. p. 292.

99 BARRETO, Tobias. Estudos de direito. Rio de Janeiro; Sergipe: J. E. Salomon; Editora Diário Oficial, 2012. v. 1. p. 176.

100 BARRETO, Tobias. Estudos de direito. Rio de Janeiro; Sergipe: J. E. Salomon; Editora Diário Oficial, 2012. v. 1. p. 218.

101 LOSANO, Mario. Tobias Barreto, um giurista tropicale: Tobias Barreto fra Brasile reale e Germania ideale. Roma; Bari: Laterza, 2000. BLUNTSCHLI, Johann Caspar. The theory of the state. Oxford: Clarendon, 1885.

102 BLUNTSCHLI, Johann Caspar. The theory of the state. Oxford: Clarendon, 1885.

103 BLUNTSCHLI, Johann Caspar. Le droit public general. Paris: Guillaumin, 1880. BLUNTSCHLI, Johann Caspar. La politique. Par- 
also quoted and explored on an article in the Allgemeine Deutsche Biographie $e^{104}$.

Tobias Barreto had constructed his copyrights law doctrine out of Bluntschli's work ${ }^{105}$. In the context of Brazilian private law Barreto is acknowledged as the first scholar to mention copyrights. Barreto had quoted Bluntschli in a paper on this subject, arguing that the German author discussed "[...] copyrights in a section concerning personal rights, right after legal entities"106. Generally speaking, the issue of classification on Private Law was fairly vexed in the XIX th century. The classical plan, according to Gaius, known as the Roman-French plan understood Private Law in three distinct sections, namely: persons, things and actions. This is the framework of the French Civil Code, as well as the codes of Austria, Argentine and Italy. The concept of Bluntschli, accepted by Tobias Barreto, follows this logic.

Bluntschli was quoted by Barreto on a cited quarrel he had against Jose Higino, a professor at the Law School in Recife. Barreto used the authority of Bluntschli to emphasize that beyond Public and Private Law there was no room for a third gender, namely, Social $\mathrm{Law}^{107}$. This issue was sustained again in the XX century, when the nature of Labor Law was discussed.

Just after this set of thinkers, Rudolf von Jhering, Rodolf Gneist, Theodor Mommsen and Johann Caspar Bluntschli, there comes a second group, which is less known today, even in the German context, notwithstanding the fact that some of them are cited on reference books. They were less influential in Barreto's conceptual framework. I mention Joseph Stövös (who was Hungarian), Albert Berner, Franz von Holtzendorff, Heinrich Lammasch, Julius Fröbel, Franz Adickes, Maximilian von Buri, Felix Dahn, Rudolf Haym, Hugo Meyer, Theodor Mutter, Conrad Franz Rosshirt, Ernest Traugott Rubo, Salomon Stricker, Adolf Samuely, August von Bethmann-Hollweg, Theodor Reinhold Schüt-

is: Guillaumin, 1883. BLUNTSCHLI, Johann Caspar. Thérie générale de l'état. Paris: Guillaumin, 1877.

104 KNONAU, Meyer Von; BLUNTSCHLI, Johann Kaspar. In: ALLGEMEINE Deutsche Biographie, 1903. Availabe: <http:// www.deutsche-biographie.de/pnd118512129.html>. Accessed on: Dec, 10th, 2014. P. 1-16.

105 BARRETO, Tobias. Estudos de direito. Rio de Janeiro; Sergipe: J. E. Salomon; Editora Diário Oficial, 2012. v. 1. p. 281.

106 BARRETO, Tobias. Estudos de direito. Rio de Janeiro; Sergipe: J. E. Salomon; Editora Diário Oficial, 2012. v. 1. p. 283.

107 BARRETO, Tobias. Estudos de direito. Rio de Janeiro; Sergipe: J. E. Salomon; Editora Diário Oficial, 2012. v. 1. p. 199-200. ze, Otto Stobbe, Emil Kraeplin, Edward Böcking, Karl Bolgiano and Friedrich Oskar Schwarze.

As stated, Joseph Stövos (1813-1871) was Hungarian. Albeit publishing some books in Germany, he was an important name in his home country, due to his contributions to literature, political science and pedagogy. He was a Ministry of Hungarian Education (18671871) position that had allowed him to advance some educational improvements ${ }^{108}$. In the Max-Planck Institut für Europäische Rechtsgeschiche library there is a sample of a 1851 edition of a Joseph Stövös work entitled Der Einfluss der herrschenden Ideen des 19. Jabrbunderts auf den Staat ${ }^{109}$; the book was printed in Wien. Tobias Barreto had the same text, although an 1854 edition printed in Leipzig. This book is referred in the 1882 Katalog der Bibliotek des Deutschen Reichstages ${ }^{110}$.

Tobias Barreto had mentioned a book from Stövos, "[...] an important paper from Baron Joseph Stövos, entitled Ueber die Gleich berechtigung der Nationalitaten in Oesterreich" "11, which confirms that he was acquainted with the events on Hungary. This quotation belongs to a context of a passionate discussion against Tavares Bastos, a Brazilian stateman in the issue of federalism. Barreto considered Stövos as an "distinguished and authoritative Hungarian writer"112.

Alfred Berner (1818-1907), another author known by Barreto, has an entry in the Neue Deutsche Biographuie, ${ }^{113}$, as well as in the Deutsche Biographische Enayklopädie ${ }^{114}$; his work is mentioned in the 1882 Katalog der Bibliotek des Deutschen Reichstages ${ }^{115}$. In the Max-Planck Institut für Europäische Rechtsgeschiche library there is an 1861 edition of

108 BÖDY, Paul. Joseph Eötvös and the modernization of Hungary, 1840-1870. Philadelphia: The American Philosophical Society, 1972. p. $98-110$.

109 STÖVÖS, Joseph. Der einfluss der herrschenden ideen des 19 jabrbunderts auf den staat. Wien: Jasper, Hügel \& Manz, 1851.

110 STÖVÖS, Joseph. Der einfluss der herrschenden ideen des 19 jahrbunderts auf den staat. Wien: Jasper, Hügel \& Manz, 1851. p. 37.

111 BARRETO, Tobias. Estudos de direito. Rio de Janeiro; Sergipe: J. E. Salomon; Editora Diário Oficial, 2012. v. 1. p. 166.

112 BARRETO, Tobias. Estudos de direito. Rio de Janeiro; Sergipe: J. E. Salomon; Editora Diário Oficial, 2012. v. 1. p. 153.

113 LANG-HINRICHSEN, Dietrich; BERNER, Albert Friedrich. In: NEUE Deutsche Biographie 2, 1955. Available: <http:// www.deutschebiographie. de/pnd116102500.html>. Accessed on: Dec. 10th, 2014. p. 107- 108.

114 DEUSTSCHE Biographische Enzyklopädie. v. 1. p. 463.

115 Among them: Lehrbuch des Deutschen Straffrechts (p. 543); Die Lehre von der Theilname am Verbrechen und neuren Controversen über dolus und culpa (p. 546); Lehrbuch des Deutschen Pressrechts (p. 538) and Wirkungskreis des Strafgesetzes (p. 527). 
an Albert Berner's book, Grundsätze des preussbischen Strafrechts, printed in Gothic alphabet ${ }^{116}$. This is the same issue founded in Tobias Barreto's German library. A biography of Alfred Berner was published in 1960; it was written as a doctoral dissertation; its author, Hubert Alda, emphasized Berner's prominence for Science (bedeutung für die Wissenschaft) ${ }^{117}$. Berner was translated into Italian (1887) and three of his books were reprinted in the twentieth century $\left(1968,1986\right.$ and 1996) ${ }^{118}$. It is a clue for the fact that he persists with some level of importance.

Tobias Barreto quoted Berner on an essay on Criminal Law, specifically in the issue of punishment of tentative. Barreto sided Berner, for he also defended the necessity of the punishment of preparatory criminal $\operatorname{acts}^{119}$. On the other hand, Barreto disagreed with Berner because, unlike the German author, Barreto understood that the mere orderer of the crime should be punished ${ }^{120}$.

Franz von Holtzendorff (1829-1889) has his life abridged in the Deutsche Biographische Ensyklopädie ${ }^{121}$. Holtzendorf also has his biography in the present important register of German lives ${ }^{122}$. There are many references to his work in the 1882 Katalog der Bibliotek des Deutschen Reichstages ${ }^{123}$. Many times quoted by Tobias

116 BERNER, Albert Friedrich. Grundsaetze des preussichen Strafrechts. Leipzig: Verlag von Berhnhard Tauchnilz, 1861.

117 ALDA, Hubert. Albert Friedrich Berner: eine biographie. Münster: Max Kramer, 1960. p. 136.

118 BERNER, Albert Friedrich. Abschaffung der todesstrafe. Dresden: Boetthicher, 1861. BERNER, Albert Friedrich. Grundlinien der criminalistischen imputationslehre, Frankfurt: Sauer \& Auvermann, 1968. BERNER, Albert Friedrich. Lebrbuch des deutschen Strafrechtes. Leipzig: Tauchnitz, 1866. BERNER, Albert Friedrich. Lebrbruch des deutschen Strafrechtes. Aalen: Scientia Verlag, 1986. BERNER, Albert Friedrich. Lebrbuch des deutschen Strafrechtes. Goldbach: Keip, 1996. BERNER, Albert Friedrich. Trattato de diritto penale. Milano: Vallardi, 1887. BERNER, Albert Friedrich. Wirkingskreis des strafgesetzes nach zeit, raum und personen. Berlin: Decker, 1853.

119 BARRETO, Tobias. Estudos de direito. Campinas: Bookseller, 2000. p. 321.

120 BARRETO, Tobias. Estudos de direito. Campinas: Bookseller, 2000. p. 355.

121 DEUSTSCHE Biographische Enzyklopädie. v. 5. p. 156.

122 TEICHMANN, A.; HOLTZENDORFF, Franz Von.. In: ALLGEMEINE Deutsche Biographie, 1910. Available: <http:// www.deutsche-biographie.de/pnd116970243.html>. Accessed on: Dec. 10th, 2014. p. 1-21.

123 To quote some: Die Auslieferung der Verbrecher und das Asylrecht (p. 528); Die Deportation als Strafmittel in Alter und neuer Zeit (p. 548), Eroberunger und Eroberungsrecht (p. 524); Für den Grafen Harry von Armin (p. 556), Das Irische Gefängnissystem insbesondere die Zwischenans halten vor der Entlassung der
Barreto, Holtzendorff was translated into Spanish, as well as he had extensively published in the XIX century ${ }^{124}$.

Tobias Barreto mentioned Holtzendorff in Criminal Law subjects while studying the legal meaning of the regret, which justified the punishment of tentative. Barreto recommended the reading of an essay from Holtzendorff ${ }^{125}$, Psychologie des Mordes ${ }^{126}$, in which the German author discussed the psychological aspects of homicide. In a paper on Criminal Law, Barreto quoted Holtzendorff in order to emphasize that State, Law and penalty are completely inseparable, "[...] in a sense that State, Law and penalty emerged from the very same historical roots, the same ethical necessity of human nature" ${ }^{\prime 27}$.

Tobias Barreto had also recommended Holtzendorff's Psycologie des Mordes as a book necessary to be read"128. Disserting on the mandate in Criminal Law Barreto had also quoted Holtezendorff, for whom, according to Barreto, the lawgiver silence should not be interpreted as a "proposal of riddles" 129 . It's said that Tobias Barreto had sent a letter do Holtzendorff, signed by some other professors of Recife Law School; according to Barreto, the letter was not answered ${ }^{130}$.

The present research continues with Heinrich Lammasch (1853-1920), who was born in Austria. In the Neue Deutsche Biographie ${ }^{131}$ there is an entry on him. His

Sträfflinge (p. 551); Die Kürzungsfähigkeit der Freihetsstrafen un die bedingte Freilassung der Sträflinge in ihrem Verhältmiss zum Strafmasse und zu den Strafzwecken (p. 549).

124 HOLTZENDORFF, Franz Von. Allgemeines Staatsrecht und Politik, München, 1874. Madrid: Fé, 1888. HOLTZENDORFF, Franz Von. De rebus quarum commercium non est. Berolini: Schlesinger, 1852. HOLTZENDORFF, Franz Von. Eroberungen und eroberungsrecht. Berlin: Lüderitz, 1871. HOLTZENDORFF, Franz Von. Die idee des ewigen völkefriedens. Berlin: Habel, 1882. HOLTZENDORFF, Franz Von. Zeitglossen des gesunden menschenverstandes. München: Ackerman, 1884. v. 2.

125 BARRETO, Tobias. Estudos de direito. Rio de Janeiro; Sergipe: J. E. Salomon; Editora Diário Oficial, 2012. p. 256.

126 Albeit with this title there is alson another book in German: BJERRE, Andreas. Zu psychologie des mordes. Heildelberg: Winter im Komm, 1925.

127 BARRETO, Tobias. Estudos de direito. Campinas: Bookseller, 2000. p. 186.

128 BARRETO, Tobias. Estudos de direito. Campinas: Bookseller, 2000. p. 324.

129 BARRETO, Tobias. Estudos de direito. Campinas: Bookseller, 2000. p. 342.

130 BARRETO, Tobias. Estudos de direito. Campinas: Bookseller, 2000. p. 53.

131 SIMMA, Bruno; LAMMASCH, Heinrich. In: NEUE Deutsche Biographie 13, 1982. Available: <http://www.deutsche-biographie.de/ pnd118726110.html>. Accessed on: Dec. 10th, 2014. p. 447-448. 
biography is included in the Deutsche Biographische Enzylklopädie ${ }^{132}$; Michael Stolleis also mentioned him. There is a 1926 edition of one of his books (Grundriss des Österreichischen Strafrechts) ${ }^{133}$ in the Max-Planck Institut für Europäische Rechtsgeschiche library. Lammasch lectured in Wien. Theodor Rittler, once Law Professor in Innsbruck, updated the book. Lammasch's expertise in International Law guaranteed him a seat at The Hague International Court of Justice. He wrote most of his books in the realm of International Law ${ }^{134}$. He defended the creation of the League of Nations. In this sense, he was a forerunner of institutional arrangements built in order to achieve the peace among the nations.

There is also Julius Fröbel (1805-1893) who has also one of his books in the catalog of Tobias Barreto's German library. In the Max-Planck Institut für Europäische Rechtsgeschiche library there is a 1971 edition from a Frobel's book, first published in $1878^{135}$. Fröbel had a great impact upon Tobias Barreto, particularly for his ideas supporting social Darwinism. Fröbel concepts were explored by Rainer Koch, who somewhat questioned Fröbel's alleged liberalism ${ }^{136}$. Fröbel was the typical nineteenth century revolutionary. Although once having Swiss citizenship, and later on, American, he represented German in Turkey and then in Algeria. Tobias Barreto had once mentioned that Fröbel was Robert Blum's friend of all battles ${ }^{137}$. Blum was a martyr of the 1848 German revolution, who was crudely executed in Wien. Fröbel has his biography on the Allgemeine Deutsche Biographie ${ }^{138}$.

Tobias Barreto included Fröbel on a syllabus prepared for a course in Public Law, as a reference for studying

132 DEUSTSCHE Biographische Enzyklopädie. v. 6. p. 206.

133 LAMMASCH, Heinrich. Grundris der österreichischen strafrechts. Wien: Druck und Verlag der Österr Staatsdruckerei, 1926.

134 LAMMASCH, Heinrich. Auslieferungspflicht und Asylrecht. Leipzig: Duncker und Humblot, 1887. LAMMASCH, Heinrich. Das recht der auslieferung wegen politischer verbrechen. Wien: Manz, 1884. LAMMASCH, Heinrich. Die rechtskeraft internationaler schiedssprüche. München: Duncker und Humblot, 1913. LAMMASCH, Heinrich. Die Völkerrecht nach dem Kriege, Kristiania: aschehoug, 1917. Studien zum Strafgesetzentwurfe; Wien: Manz, 1891.

135 FRÖBEL, Julius. Die gesichtspunkte und aufgaben der politik. Darmstadt: Scientia Verlag, 1971.

136 KOCH, Rainer. Demokratie und Staat bei Julius Fröbel: 18051893, liberales denken zwischen naturrecht und sozialdarwinismus. Wiesbaden: Franz Steiner Verlag, 1978.

137 BARRETO, Tobias. Estudos de direito. Campinas: Bookseller, 2000. p. 58.

138 SANDER, Heinrich, FRÖBEL; Julius. In: ALLGEMEINE Deutsche Biographie, 1904. Available: <http://www.deutsche-biographie.de/pnd118536303.html>. Accessed: Dec., 14th, 2014. p. 1-14. the definition of State as a cultural power evocated for a particular History ${ }^{139}$. Fröbel was also the reference that Barreto used to discuss the role of political oratory, in a sense that word flux would be the mechanisms always at the Government's and opposition's service ${ }^{140}$. He incidentally criticized the behavior of the French political orators, for whom the shape was more important than the content ${ }^{141}$.

Acquainted with the works of Fröbel, Barreto had corrected a contender, on a debate in the Recife's newspapers. The competitor had quoted Fröbel old ideas, that is, according to Barreto, "the ideas imputed to Fröbel are already abandoned by the author on a preamble of one of his latest works" "12. Barreto had recent Fröbel's books in his library shelves. Barreto had quoted Fröbel in order to argument that the organization of society is done by laws out of which there was a coercive power ${ }^{143}$.

Fröbel was furthermore quoted by Tobias on a paper on which the Brazilian author had criticized Sociology; in the context, Tobias argued that Sociology could not be more than a chapter of a General Theory of Politics ${ }^{144}$, as well as he insisted that the State subordinate society to its desires ${ }^{145}$. Tobias Barreto also repeated Fröbel on a debate about the nature of selfgovernment, suggesting his opponent to read Fröbel's "System der socialien Politik" "146. The knowledge of German authors was a powerfull weapon vastly utilized by Tobias Barreto.

The culturalism - a landmark on Tobias Barreto's thought - somehow is linked to Fröbel's. On a paper written about the topic "a new intuition to Law" Barreto sided Fröbel in order to state that culture, as opposed to nature, is a general process of life $\mathrm{e}^{147}$.

139 BARRETO, Tobias. Estudos de direito. Rio de Janeiro; Sergipe: J. E. Salomon; Editora Diário Oficial, 2012. v. 1. p. 66.

140 BARRETO, Tobias. Estudos de direito. Rio de Janeiro; Sergipe: J. E. Salomon; Editora Diário Oficial, 2012. v. 1. p. 130.

141 BARRETO, Tobias. Estudos de direito. Rio de Janeiro; Sergipe: J. E. Salomon; Editora Diário Oficial, 2012. v. 1. p. 131.

142 BARRETO, Tobias. Estudos de direito. Rio de Janeiro; Sergipe: J. E. Salomon; Editora Diário Oficial, 2012. v. 1. p. 198. In: Portuguese: "as ideias que contém já foram solenemente desaprovadas pelo próprio autor no prólogo de um de seus trabalhos mais recentes".

143 BARRETO, Tobias. Estudos de direito. Rio de Janeiro; Sergipe: J. E. Salomon; Editora Diário Oficial, 2012. v. 1. p. 200.

144 BARRETO, Tobias. Estudos de direito. Campinas: Bookseller, 2000. p. 58.

145 BARRETO, Tobias. Estudos de direito. Campinas: Bookseller, 2000. p. 59.

146 BARRETO, Tobias. Estudos de direito. Rio de Janeiro; Sergipe: J. E. Salomon; Editora Diário Oficial, 2012. v. 1. p. 199.

147 Cf. BARretO, Tobias. Estudos de direito. Campinas: Book- 
Franz Adickes (1846-1915), another German author known by Tobias Barreto, was once a Frankfurt's Mayor, as well of one of the Johann Wolfgang Goethe Universität founders. He was educated in Heidelberg, Munich and Göttingen. According to Mario Losano, Tobias Barreto had one book written by Franz Adickes in his library ${ }^{148}$. This very edition is available at the Max-Planck Institute for European Legal History. The 1882 German Parlament Cathalog also mentioned a book authored by Franz Adickes ${ }^{149}$, whose biography is likewise in the Neue Deutsche Biographie ${ }^{150}$. Franz Adickes had written a book deffending the reorganization of the bench $^{151}$, as well as a book on Law History ${ }^{152}$. However, on a literary perspective, he presently is more evoked as a memorialist ${ }^{153}$.

Tobias Barreto quoted Adickes on an essay on copyrights, on a transcription from an excerpt from the German author, which he translated into Portuguese ${ }^{154}$. In this passage Tobias Barreto criticized the concept of Natural Law, arguing that this notion could not be tantamount as an oracle of truths ${ }^{155}$.

It follows Maximilian von Buri (1825-1902) who had expertise on Criminal Law, a field in which the proficiency of Tobias Barreto is yet to be enphasized. Buri's main book was in the shelves of Tobias Barreto's personal library ${ }^{156}$. At at the Max-Planck Institute for Euro-

seller, 2000 p. 102.

148 LOSANO, Mario. Tobias Barreto, un giurista tropicale: Tobias Barreto fra Brasile reale e Germania ideale, Roma; Bari: Laterza, 2000. p. 257. ADICKES, Franz. Zur Lebre von den Rechtsquellen, insbesondere über die Vernung und die Natur der Sache als Rechtsquellen um über das Gewohnheitsrecht. Leipzig: G. H. Wigand, Cassel \& Göttingen, 1872.

149 KATALOG der Bibliotek des Deutschen Reichstages, 1882. p. 383.

150 MEINERT, Hermann; ADICKES, Franz. In: NEUE Deutsche Biographie 1, 1953. Available: <http://www.deutschebiographie.de/pnd118647008.html>. Accessed on: Dec., $14^{\text {th }}, 2014$. p. 61-62.

151 ADICKES, Franz. Grundlinien durchgreifender Justizreform. Berlin: Guttentag, 1906.

152 ADICKES, Franz. Zur Lehre von den Bedingungen nach römischem und heutigem Recht. Berlin: Guttentag, 1876.

153 ADICKES, Franz. Persönliche Erinnerungen zur Vorgescbicbte der Universität Frankfurt a. M. Frankfurt: Englert \& Schlosser, 1915.

154 BARRETO, Tobias. Estudos de direito. Rio de Janeiro; Sergipe: J. E. Salomon; Editora Diário Oficial, 2012. v. 1. p. 287.

155 BARRETO, Tobias. Estudos de direito. Rio de Janeiro; Sergipe: J. E. Salomon; Editora Diário Oficial, 2012. v. 1. p. 287.

156 LOSANO, Mario. Tobias Barreto, un giurista tropicale: Tobias Barreto fra Brasile reale e Germania Ideale, Roma; Bari: Laterza, 2000. p. 258. BURI, Maximilian Von. Carl Kirchner: Buri, Maximilian Georg Wilhelm Carl Theodor Gottfried von. In: NEUE Deutsche Biographie (NDB). Ueber Causalität und deren Verantwortung: Leipzig, pean Legal History collection, there is a sample of this book, which might be somewhat significant, for it was reprinted in $1968^{157}$. Von Buri was known due to its influences to the Criminal Law theory ${ }^{158}$, as well as for his studies in the ground of the agent-causation theory ${ }^{159}$. He is biographed by the Neue Deutsche Biographie ${ }^{160}$, which confirms his importance in the milieu of German culture.

Tobias Barreto quoted von Buri on a footnote, in his critical commentary to the Brazilian Criminal Code. Barreto pointed that von Buri was an important source for the study of some peculiarities of criminal law, especially in the setting of criminal liability ${ }^{161}$. Barreto also quoted von Buri on an essay he wrote about crimes by omission, as in the following passage, that I freely translate from Portuguese:

[...] $\mathrm{M}$, on a travel to a certain place, has to pass necessarily by the doors of a house, propriety of $\mathrm{N}$, who lives in the bank of a river, in which there is a bridge of a general and everyday use. It happens, however, that in this very day the bridge is somewhat deteriorated and cannot be use without any danger for its customers. $\mathrm{M}$ ignores, but $\mathrm{N}$ knows about this fact; as for the imminent catastrophe $\mathrm{N}$ does not warn the passer-by, and also he is delighted in watching the spectacle, cynically speaking: let us see the fall of that demon. Said and done: $\mathrm{M}$ falls from the ruined bridge e broke his leg. Was not $\mathrm{N}$ culpable? I think it is quite fair, according to von Buri, that we were going far enough with a principle of Law, which makes anyone liable for the result of an act that he could, if he needed, had avoided, if one transcends this principle, with no limits, from the realm of Ethics to the realm of Criminal Law. But also it seems to me unquestionable that it would be hard to maintain the order and tranquility of a society, where similar facts had by only obstacle, or as an unique corrective the voice of a moral conscience, which is relative to idiosyncrasies, according to education, temper and habitual $\operatorname{passion}^{162}$.

1873. p. 116-117.

157 BURI, Maximilian Von. Einheit und mebrheit der verbrechen. Frankfurt am Main: Keip, 1968.

158 BURI, Maximilian Von. Beiträge zur theorie des strafrechts und zum strafgesetz̧buche. Leipzig: Veit, 1894.

159 BURI, Maximilian Von. Die causalität und ibre strafrecbtlichen beziebungen. Stuttgart: Enke, 1885.

160 KIRCHNER, Carl; BURI, Maximilian. Georg Wilhelm Carl Theodor Gottfried von. In: NEUE Deutsche Biographie 3, 1957. Available: <http://www.deutsche-biographie.de/pnd115488103. html>. Accessed on: Dec., 14 ${ }^{\text {th }}$, 2014. p. 51-52.

161 BARRETO, Tobias. Estudos de direito. Campinas: Bookseller, 2000. p. 253.

162 BARRETO, Tobias. Estudos de direito. Campinas: Bookseller, 2000. p. 307. In Portuguese: "[...] M, em viagem para um certo lugar, 
It continues with Felix Dahn (1834-1912), a nationalist and a notorious historian. He was born in Hamburg, educated in Munich and in Berlin. Tobias Barreto had a book written by Dahn; the topic was German private $\operatorname{law}^{163}$. At the Max-Planck Institute for European Legal History library, there is a sample of this book, exactly the same edition that Barreto had. In 1882, Felix Dahn had eight of his books categorized in the German Parliament library catalog ${ }^{164}$. Tobias Barreto quoted Felix Dahn in his essay on copyrights, mentioning him as the "wise professor of Koenisberg" 65 . Felix Dahn authored books on History ${ }^{166}$, one of them edited in $1857^{167}$ and reprinted in $1998^{168}$. His biography is also in the Neue Deutsche Biographie ${ }^{169}$.

Barreto had known also Rudolf Haym (1821-1901) a notorious historian of the 1848 Frankfurt National Assembly, in which he occupied a seat. In the 1930's Hans Rosenberg had written Haym's biography ${ }^{170}$. Mario Losano noticed a Rudolf Haym's book in Tobias

tem de passar necessariamente pela porta da casa de $\mathrm{N}$, que mora à margem de um rio, sobre o qual há uma ponte de trânsito geral e quotidiano. Sucede, porém, que nesse dia a ponte se acha deteriorada e não é transitável sem perigo. $\mathrm{M}$ ignora, mas $\mathrm{N}$ conhece esse estado; e não só deixa de advertir o transeunte da catástrofe iminente, como ainda se comprar em assistir ao espetáculo, dizendo cinicamente: vejamos a queda daquele demônio. Dito e feito; $\mathrm{M}$ cai da ponte arruinada e quebra uma perna. Não haverá imputabilidade criminosa no proceder de $\mathrm{N}$ ? Eu acho na verdade justo o que diz Von Buri, que seria ir muito longe com o princípio de direito, que faz a qualquer responsável pelo resultado de um ato, que ele pudera, querendo, ter evitado, se se transportasse esse princípio, sem limitação alguma, do domínio da ética para o domínio do direito penal. Mas também me parece inquestionável que seria difícil de conservarse num certo pé de ordem e tranquilidade uma sociedade, onde fatos de semelhante natureza tivessem por único óbice, ou por corretivo único a voz da consciência moral, que é relativa às individualidades, segundo a educação, o seu temperamento e suas paixões habituais". 163 LOSANO, Mario. Tobias Barreto, un giurista tropicale: Tobias Barreto fra Brasile reale e Germania Ideale. Roma; Bari: Laterza, 2000. p. 258. DAHN, Felix. Deutsches privatrecht. Leipzig: Breitkoppf und Härtel, 1872.

164 KATALOG der Bibliotek des Deutschen Reichstages, 1882. p. 1289.

165 BARRETO, Tobias. Estudos de direito. Campinas: Bookseller, 2000. p. 284.

166 DAHN, Felix. Westgothische studien. Würzburg: Stahel, 1874.

167 DAHN, Felix. Studien zur geschichte der germanischen gottes-urtheile. München: [s. n.], 1857.

168 DAHN, Felix. Studien zur geschicbte der germanischen gottes-urtheile. Dillenburg: Gruber, 1998.

169 MARTINI, Fritz; DAHN, Julius Sophus Felix. In: NEUE Deutsche Biographie 3. 1957. Available: <http://www.deutsche-biographie.de/pnd118523392.html>. Accessed on: Dec., 14th, 2014. p. $482-484$.

170 ROSENBERG, Hans. Rudolf Haym und die anfänge des klassischen liberalismus. München: Oldenbourg, 1933.
Barreto's German library ${ }^{171}$. There is a copy of this text at at the Max-Planck Institute for European Legal History library.

The 1882 German Parliament catalog listed five books written by Rudolf Haym $^{172}$. Tobias Barreto had quoted Haym in a passionate controversy he had against a colleague at the Recife Law School (Jose Higino). Tobias Barreto claimed Haym's authority in order to sustain that during the German national assembly at Frankfurt (circa 1848), the local autonomy was acknowledged as a fundamental right ${ }^{\prime 173}$. One must recognize how well Tobias Barreto exploited his bibliographical sources. In this very particular case, he evidenced a fact happened in the German national assembly quoting one of its members.

There is also Hugo Meyer (1837-1902), who commented the German Penal Code. He went to Law School in Gottingen and Berlin, while he was later a Law professor in Halle and Tubingen. Mario Losano detected a damaged sample of the Meyer's book at Tobias Barreto library. He had lately gathered this book missed information in the Munich State Library (Bayerische Staatsbibliotek) $)^{174}$. At the Max-Planck Institute for European Legal History there are two editions of this book; one, from 1875, published in Erlangen ${ }^{175}$, and another, edited in 1907, from the same publishers, albeit printed in Leipzig ${ }^{176}$. In addition to the book encountered in Tobias Barreto's library, Hugo Meyer had written another volume on Criminal Law, published in $1869^{177}$. The 1882 German Parliament catalog listed three books authored by Hugo Meyer ${ }^{178}$.

171 LOSANO, Mario. Tobias Barreto, un giurista tropicale: Tobias Barreto fra Brasile reale e Germania Ideale. Roma; Bari: Laterza, 2000. p. 260. RAYM, Rudolf. Die deutsche nationalversammlung bis zu septemberereignissen. Frankfurt: Carl Jügel, 1848.

172 KATALOG der Bibliotek des Deutschen Reichstages, 1882. p. 1322.

173 BARRETO, Tobias. Estudos de direito. Rio de Janeiro; Sergipe: J. E. Salomon; Editora Diário Oficial, 2012. v. 1. p. 196.

174 LOSANO, Tobias Barreto, un giurista tropicale: Tobias Barreto fra Brasile reale e Germania Ideale. Roma; Bari: Laterza, 2000, p. 262. MEYER, Hugo. Lebrbuch des dentsches strafrechts. Erlangen: Deichert, 1882.

175 MEYER, Hugo. Lebrbuch des deutschen strafrechts. Erlangen: Deichert, 1875.

176 MEYER, Hugo. Lehrbuch des deutschen strafrechts. Leipzig: Deichert, 1907.

177 MEYER, Hugo. Das norddentsche strafrecht. Halle: Waisenhauses, 1869 .

178 KATALOG der Bibliotek des Deutschen Reichstages, 1882. p. 1359. 
The list continues with Theodor Muther (18261878), professor at Iena and gained celebrity due to the dispute he had against Bernhard Windscheid (18171892) a propos of the alleged autonomy of civil process in the face of subjective rights. Windscheid was "an execrate foe of the natural rights theory and its mythology" "179, to whom the Roman Law "action" had been unsuitably considered in Germany (especially by Savigny).

Mario Losano observed that Tobias Barreto had a book from Mutter in his library, on the subject of the restructuring German Law School approaches and curricula ${ }^{180}$. This book is available at the Max-Planck Institute for European Legal History library, also in a reprinted edition, dated from $1968^{181}$. Tobias Barreto had quoted it, deffending the the reformation of the Brazilian law schools, which he understood as unavoidable ${ }^{182}$. Mutter was also a law historian, subject in which he penned a book on the Roman and Canonic Law in Germany Middle Ages ${ }^{183}$. The 1882 German Parliament catalog listed three books authored by Theodor Mutter ${ }^{184}$.

A book from Conrad Franz Rossirt was also among Tobias Barreto's German tomes ${ }^{185}$. Rossirt wrote on Roman Law ${ }^{186}$, Canonical Law ${ }^{187}$, its sources ${ }^{188}$, Pro-

179 GROSSI, Paolo. L'Europa del diritto. Roma-Bari: Laterza, 2007. p. 169. Originally: "nemici giurati del giusnaturalismo e delle sue mitologie".

180 LOSANO, Tobias Barreto, un giurista tropicale: Tobias Barreto fra Brasile reale e Germania Ideale. Roma; Bari: Laterza, 2000, p. 262, and the mentioned book is MUTHER, Theodor. Die reform des juristischen unterrichts. Weimar: Böhlau 1873.

181 MUTHER, Theodor. Die reform des juristischen unterrichts. Frankfurt: Keip, 1968.

182 BARRETO, Tobias. Estudos de direito. Campinas: Bookseller, 2000. p. 80.

183 MUTHER, Theodor. Roemisches und kanonisches recht im deutschen mittelalter. Rostock: Kuhn, 1871.

184 KATALOG der Bibliotek des Deutschen Reichstages, 1882. p. 1365.

185 LOSANO, Tobias Barreto, un giurista tropicale: Tobias Barreto fra Brasile reale e Germania Ideale. Roma; Bari: Laterza, 2000, p. 262 and the mentioned book is ROSSIRT, Conrad Franz. Entwickelung der grundsätze des strafgesetz̧buch für das deutsche reich unda einfübrunggsgeset\%. Berlin: Carl Heymanns, 1872.

186 ROSSHIRT, Conrad Franz. Einleitung in das erbrecht und darstellung des ganzen intestat-erbrechts, besonders nach römischen quellen. Landshut: Krüll, 1831.

187 ROSSHIRT, Conrad Franz. Canonisches recht. Schaffhausen: Hurter, 1857.

188 ROSSHIRT, Conrad Franz. Zu den kirchenrechtlichen quellen des ersten jahrtausends und zu denpseudoisidorischen decretalen. Heidelberg: Mohr, 1849. cess $^{189}$ and Civil Law ${ }^{190}$. Tobias Barreto defined Rossirt as an expert of Criminal Law, warden of Natural Law, to which he was totally opposed ${ }^{191}$. Tobias Barreto once entitled Rossirt as an "old Latinized criminalist"192, for the German author regarded delinquency under the forms of authorship and complicity ${ }^{193}$. In one of his essays, Tobias Barreto quoted Rossirt, as an argument for criticizing the open interpretation of criminal law ${ }^{194}$.

Barreto had known also Ernst Traugott Rubo (18341895), educated in Heidelberg, skilled on Criminal Law, who was a magistrate in Berlin. Tobias Barreto had one his books, a commentary on the German Criminal Code ${ }^{195}$. At the Max-Planck Institute for European Legal History there are two samples of this tome; one edition from $1879^{196}$ and another one from the twentieth century, printed in $1922^{197}$. The 1882 German Parliament catalog listed three books written by Ernest Rubo ${ }^{198}$. Tobias Barreto quoted Rubo on an essay ${ }^{199}$, exploiting the boundaries that apart ethical and juridical features of criminal law.

Samuel Stricker (1834-1898), who is also among the authors Tobias Barreto have assembled in his library, although almost rarely cited, has a book on the Max-Planck Institut für Europäische Rechtsgeschiche library. It is exactly the same one (title and edition) that Tobias Barreto had in his collection. The text explores the differences between Recht and Gesetz $2^{200}$, viz., a general concept of a

189 ROSSHIRT, Conrad Franz. Beiträge zum gemeinen deutschen prozeß. Heidelberg: Mohr, 1868.

190 ROSSHIRT, Conrad Franz. Ueber die tendenz des prätorischen rechts und über das verbältniss desselben zum civilrecbte. Erlangen: Hilpert, 1812.

191 BARRETO, Tobias. Estudos de direito. Rio de Janeiro; Sergipe: J. E. Salomon; Editora Diário Oficial, 2012. v. 1. p. 184.

192 BARRETO, Tobias. Estudos de direito. Rio de Janeiro; Sergipe: J. E. Salomon; Editora Diário Oficial, 2012. v. 1. p. 338.

193 BARRETO, Tobias. Estudos de direito. Rio de Janeiro; Sergipe: J. E. Salomon; Editora Diário Oficial, 2012. v. 1.

194 BARRETO, Tobias. Estudos de direito. Campinas: Bookseller, 2000. v. 2. p. 44.

195 LOSANO, Tobias Barreto, un giurista tropicale: Tobias Barreto fra Brasile reale e Germania Ideale. Roma; Bari: Laterza, 2000, p. 262 and the above quoted book is RUBO, Ernst Traugott. Kommentar über das strafgesetzbuch für das deutsche reich. Frankfurt: Keip, 1992.

196 RUBO, Ernst Traugott. Kommentar über das strafgesetzbuch für das deutsche reich. Frankfurt: Keip, 1992.

197 RUBO, Ernst Traugott. Kommentar über das strafgesetz̧ buch für das deutsche reich. Frankfurt: Keip, 1992.

198 KATALOG der Bibliotek des Deutschen Reichstages, 1882. p. 1389.

199 BARRETO, Tobias. Estudos de direito. Rio de Janeiro; Sergipe: J. E. Salomon; Editora Diário Oficial, 2012. v. 1. p. 325.

200 STRICKER, Salomon. Physiologie des rechts. Wien: Teoplitz \& 
legal order contrasting a very particular notion of a legal rule. Between the lines, Stricker considered the divergences between Natural Law and Positive Law, a nuclear question in the nineteenth century conceptual agenda.

Adolf Samuely, although cited by Michael Stolleis, is an author whose legacy is difficult to map. In the Max-Planck Institut für Europä̈sche Rechtsgeschiche library there is an Adolf Samuely essay dated of $1875^{201}$. The essay is a commentary on an article of the Swiss Constitution. Samuely lectured at the University of Bern. His liberal approach towards religion was close to the laicism that Tobias Barreto had enduringly defended. Tobias Barreto quoted Samuely, from whom he copied a paragraph, while discussing the state secretary's liability on a parliamentary regime. The quote referred to the Samuely conclusions regarding the impeachment in the English Parliament. Similarly, in another passage, Tobias cited Samuely to sustain that a civil servant that practices any crime, and not only the ones directly related to its duties, does severely violate the obligations he has to accomplish.

August von Bethmann-Hollweg (1795-1877) is another author whose work Tobias Barreto was familiar. Even though Bethmann-Hollweg is rarely mentioned in general, there is an 1864 edition of one of his books in the Max-Planck Institut für Europäische Rechtsgeschiche collection ${ }^{202}$. It is a study on Roman Civil Process, a subject that Tobias Barreto effectively had some familiarity. Tobias Barreto quoted Bethmann-Hollweg in an essay he wrote on the civil process in the context of Roman $\mathrm{Law}^{203}$. In order to challenge the recognized division of the Roman Law species of legis actiones ${ }^{204}$, Tobias Barreto confirmed Bethmann-Hollweg authority to contest this conservative taxonomy ${ }^{205}$. Some of Bethmann-Hollweg books were reprinted in the twentieth century ${ }^{206}$. More

Deutick, 1884. p. 61.

201 SAMUELY, Adolf. Artikel 50 der schweirzerischen bundesverfassung vom 20 mai 1874. Bern: Buchdrukerei von Jent \& Reinert, 1874.

202 BETHMANN-HOLLWEG, August Von Der. Römische civilprozess. Bonn: Aldolph Mareus, 1864.

203 BARRETO, Tobias. Estudos de direito. Rio de Janeiro; Sergipe: J. E. Salomon; Editora Diário Oficial, 2012. v. 1. p. 311.

204 Namely: sacramento, per judicis postulacionem, per condictionem, per manus injectionem, per pignoris capionem. BARRETO, Tobias. Estudos de direito. Rio de Janeiro; Sergipe: J. E. Salomon; Editora Diário Oficial, 2012. v. 1. p. 312.

205 BARRETO, Tobias. Estudos de direito. Rio de Janeiro; Sergipe: J. E. Salomon; Editora Diário Oficial, 2012. v. 1.

206 HOLLWEG, August Von Bethmann. Gerischtsverfassung und prozess des sinkenden römischen reichs. Frankfurt: Keip, 1970. HOLLWEG, August Von Bethmann. Unsprung der lombardischen städtefreiheit. Amsterdam: Bonset, 1971. common, however, are the XIX th century editions ${ }^{207}$. Bethmann-Hollweg had also written an interesting book of his memories of Savigny ${ }^{208}$.

Next, Theodor Reinhold Schütze (1827-1897), who was educated in Kiel and in Munich. Two of his books, both in the field of Criminal Law, are listed on Tobias Barreto's German library catalog ${ }^{209}$. At the Max-Planck Institute for European Legal History library there are some samples of the mentioned books. The 1882 German Parliament catalog registers one book authored by Theodor Schütze ${ }^{210}$. On a commentary that Tobias Barreto had written on the Brazilian Criminal Code he quoted and criticized Thedor Schütze ${ }^{211}$, circumstance that confirms his acquaintance with this German author.

There is also Otto Stobbe (1831-1897), historian and law professor, who studied in Konigsberg. He was subsequently a professor in Breslau, Leipzig and Konigsberg, his alma mater. Tobias Barreto had one of his books ${ }^{212}$. Stobbe had written on the history of German law sources ${ }^{213}$, as well as on the Jews in German during the middle Ages, a book that was printed in $1923^{214}$. He also wrote a textbook on German private law, and a history of copyrights, which have two editions ${ }^{215}$ The 1882 German Parliament catalog enlisted five Otto Stobbe's books ${ }^{216}$.

207 HOLLWEG, August Von Bethmann. Grundriss zu pandektenvorlesungen. Frankfurt: Broenner, 1831. HOLLWEG, August Von Bethmann. Ueber gesetagebung und rechtswissenschaft als aufagabe unserer zeit. Bonn: Marcus, 1876.

208 HOLLWEG, August Von Bethmann. Erinnerung an Friedrich Carl Von Savigny-als rechtlehrer, staatsmann und schift. Weimar: Hermann Böhlan, 1867.

209 LOSANO, Tobias Barreto, un giurista tropicale: Tobias Barreto fra Brasile reale e Germania Ideale. Roma; Bari: Laterza, 2000, p. 264 and the mentioned book is SCHÜTZE, Theodor Reinhold. Lebrbuch des deutschen strafrechts. Leipzig: J. M. Gebhardt, 1874. SCHÜTZE, Theodor Reinhold. Die nothiwendige theilnahme am verbrechen. Leipzig: J. M. Gebhardt, 1869.

210 KATALOG der Bibliotek des Deutschen Reichstages, 1882. p. 542.

211 BARRETO, Tobias. Estudos de direito. Rio de Janeiro; Sergipe: J. E. Salomon; Editora Diário Oficial, 2012. v. 1. p. 247.

212 LOSANO, ano, p. 264 apud STOBBE, Otto. Hanbuch des deutschen privatrechts. Berlin: W. Hertz, 1871-1878. v.3

213 STOBBE, Otto. Geschichte der deutschen Rechtsquellen. Leipzig, 1860.

214 STOBBE, Otto. Die juden in deutschland während des mittelalters in politischer, socialer und rechtlicher beziebung, verlagsort. Berlin: Lamm, 1923.

215 STOBBE, Otto. Zur Geschichte des deutschen vertragsrechts. Leipzig: [s. n.], 1855. STOBBE, Otto. Zur geschichte des deutschen vertragsrechts. Frankfurt: Minerva, 1969.

216 KATALOG der Bibliotek des Deutschen Reichstages, 1882. 
Among the least known, Emil Kraeplin (1856-1926), who was a physician; his life was briefed in the Deutsche Biographische Ensyklopädie, ${ }^{217}$ he is also cited in the $1882 \mathrm{Ka}$ talog der Bibliotek des Deutschen Reichstages ${ }^{218}$. Kraeplin insisted that mental illness had an organic component, as opposed to Sigmund Freud's theory. Furthermore, Edward Böcking (1802-1860), who has correspondingly an entry in the Deutsche Biographische Enaykklopädie ${ }^{219}$. One of his books, Pandekten des römischen, was known by Tobias Barreto. There is a sample of this work in the Max-Planck Institut für Europäische Rechtsgeschiche library; it is an 1855 edition $^{220}$.

There is also Karl Bolgiano (1816-1897), who studied in Munich and in Heidelberg. Tobias Barreto had a copy of one of his books ${ }^{221}$. Bolgiano also had written a book on Bavarian law ${ }^{222}$. The 1882 German Parliament catalog enlisted two of his books ${ }^{223}$. Lastly, Frederich Oskar Schwarze (1816-1886), criminal law specialist, who studied in Leipzig. He was a law professor in Dresden and subsequently a member of the Reichtag. Tobias Barreto had one of his books in his German library ${ }^{224}$. Tobias Barreto had quoted Schwarze on a paper he wrote on Criminal Law ${ }^{225}$.

To end with, there is deficiency of information regarding Leonhard Freund, Eugen Tuhn and Wilhelm Lagenbeck.

\section{Final Considerations}

Among the authors explored, the survey stressed a common place, that is, Rudolf von Jhering, Rodolf von

p. 1408.

217 DEUSTSCHE Biographische Enzyklopädie. v. 6. p. 62.

218 KRAEPLIN, Emil. Die abschaffung des strafnaßes. Stuttgart: F. Enke, 1880. p. 547.

219 DEUTSCHE Biographische Enzyklopädie. v. 1. p. 609.

220 BÖCKING, Eduard. Pandecten der römischen privatrechts. Leipzig: Verlag Von Sirzel, 1855.

221 LOSANO, LOSANO, Tobias Barreto, un giurista tropicale: Tobias Barreto fra Brasile reale e Germania Ideale. Roma ; Bari: Laterza, 2000, p. 258 and the quoted book is BOLGIANO, Karl. Handbuch des rechtscivil-processrechts. Stuttgart: F. Enke, 1879.

222 BOLGIANO, Karl. Beitrag zur lehre vom rückfall nach bayerischem staats rechte. München: Duncker und Humblot, 1843.

223 KATALOG der Bibliotek des Deutschen Reichstages, 1882. p.589; 590 .

224 Cf. LOSANO, Mario. Tobias Barreto, um giurista tropicale: Tobias Barreto fra Brasile reale e Germania ideale. Roma; Bari: Laterza, 2000. p. 264. SCHWARZE, Friedrich Oskar. Commentar zum strafgesetzbuch für das deutsche reich. Leipzig: Fue, 1873.

225 Cf. BARRETO, Tobias. Estudos de direito. Rio de Janeiro; Sergipe: J. E. Salomon; Editora Diário Oficial, 2012. v. 1. p. 297.
Gneist, Theodor Mommsen and Johann Caspar Bluntschli are of a vital importance in the history of German legal thought. Their reception by Tobias Barreto confirms that this Brazilian law professor was aware of the significant German scholars he studied.

The investigation also found that Josepf Eötvös, unknown among Brazilian scholars, has an overriding reputation in Hungarian political history. The research also concluded that Albert Bermer, Franz von Holtzendorf, Heinrich Lammasch, Julius Fröbel, Franz Adickes, Maximilian von Buri, Felix Dahn, Rudolf Haym, Hugo Meyer, Theodor Mutter, Conrad Franz Rossirt, Ernest Traugott Rubo, Salomon Stricker, Adolf Samuely, August von Bethamnn-Hollweg, Theodor Reinhold Schütze, Otto Stobbe, Emil Kraeplin, Edward Bocking, Karl Bolgiano and Friedrich Oskar Schwaze are known in Germany, albeit on a more restrict array of recognition. The present study also found that some authors like William Lagenbeck, Leonhard Freund and Eugene Tuhn are in that quasi-oblivion which was mentioned in the beginning of the text.

In the nineteenth century, a South American scholar could have chosen a European author by a myriad of factors. Those reasons might range from the possibility of importing the book (and in this case, some other aspects, as price and booksellers had played an important role) to the very assumption of the importance of the author, which can be applied to names as Jehring and Mommsen, with no doubts. In the nineteenth century foreign ideas were imported by Brazilian scholars, especially from Europe, although under an apparent conflict between French and German tendencies. Tobias Barreto was with no suspicions a champion of the German concepts in Brazilian cultural history.

The paper assumes that Tobias Barreto's biographers did not explain the methodology he used to select the German authors he studied. Driven by intuition, subject to booksellers' readiness to import, dependent on catalogs and limited by financial restrictions, Tobias Barreto found his own way of perceiving the German cultural legacy. This peculiarity might be one of the aspects that explains that randomness might play an important role in the history of transposition and reception of European ideas in Latin America.

Finally, it must be affirmed that the authors here cited, all known by Tobias Barreto, had their thoughts once discussed in Latin America hence confirming Tho- 
mas Duve's perception that Europe's cultural boundaries transcends its geographical limits, for the concept of Europe might be also historical and not only geographical.

\section{References}

ADICKES, Franz. Grundlinien durchgreifender justiareform. Berlin: Guttentag, 1906.

ADICKES, Franz. Persönliche erinnerungen zur vorgeschichte der universität Frankfurt a.M. Frankfurt: Englert \& Schlosser, 1915.

ADICKES, Franz. Zur lehre von den bedingungen nach römischem und heutigem Recht. Berlin: Guttentag, 1876.

ADICKES, Franz. Zur lehre von den rechtsquellen, insbesondere über die vernung und die natur der sache als rechtsquellen um über das gewohnheitsrecht. Leipzig: G. H. Wigand, Cassel \& Göttingen, 1872.

ALDA, Hubert. Albert Friedrich Berner, eine biographie. Münster: Max Kramer, 1960.

AMADO, Gilberto. Tobias Barreto. Rio de Janeiro: Ariel, 1934.

BARRETO, Luiz Antônio. Tobias Barreto: a abolição da escravatura e a organização da sociedade. Recife: Editorial de Sergipe, 1988.

BARRETO, Tobias. Estudos alemães. Rio de Janeiro; Aracaju: Record; Secretaria de Cultura e Meio Ambiente, 1991.

BARRETO, Tobias. Estudos de direito. Campinas: Bookseller, 2000.

BARRETO, Tobias. Estudos de direito. Rio de Janeiro; Sergipe: J. E. Salomon; Editora Diário Oficial, 2012. v. 1.

BECCHI, Paolo. Ideologie dela codificazione in Germania. Genova: Companhia del Librai, 1999.

BELLOMO, Manlio. L'Europa del diritto comune. Roma: I Cigno Galileo Galilei Edizioni di Arte e Scienza, 1994.

BERNER, Albert Friedrich. Abschaffung der todesstrafe. Dresden: Boetthicher, 1861.

BERNER, Albert Friedrich. Grundlinien der criminalistischen imputationslebre. Frankfurt: Sauer \& Auvermann, 1968.
BERNER, Albert Friedrich. Grundsaetze des preussichen strafrechts. Leipzig: Verlag von Berhnhard Tauchnilz, 1861.

BERNER, Albert Friedrich. Lehrbruch des deutschen strafrechtes. Aalen: Scientia Verlag, 1986.

BERNER, Albert Friedrich. Lebrbuch des deutschen strafrechtes. Goldbach: Keip, 1996.

BERNER, Albert Friedrich. Lehrbuch des deutschen strafrechtes. Leipzig, Tauchnitz, 1866.

BERNER, Albert Friedrich. Trattato de diritto penale. Milano: Vallardi, 1887.

BERNER, Albert Friedrich. Wirkingskereis des strafgesetzes nach zeit, raum und personen. Berlin: Decker, 1853.

BETHMANN-HOLLWEG, August Von Der. Römische civilprozess. Bonn: Aldolph Mareus, 1864.

BEVILACQUA, Clóvis. Tobias Barreto. In: JURISTAS Filósofos. Salvador: Livraria Magalhães, 1897. p. 75-95.

BLUNTSCHLI, Johann Caspar. Deutsches staats-wörterbuch. Editora: Stugart und Leipzig, 1858.

BLUNTSCHLI, Johann Caspar. Le droit public general. Paris: Guillaumin, 1880.

BLUNTSCHLI, Johann Caspar. The theory of the state. Oxford: Clarendon, 1885.

BÖCKING, Eduard. Pandecten der römischen privatrechts. Leipzig: Verlag Von Sirzel, 1855.

BÖDY, Paul. Joseph Eötvös and the modernization of Hungary, 1840-1870. Philadelphia: The American Philosophical Society, 1972.

BOLGIANO, Karl. Beitrag zur lebre vom rückfall nach bayerischem staats rechte. München: Duncker und Humblot, 1843.

BOLGIANO, Karl. Handbuch des rechts-civil-processrechts. Stuttgart: F. Enke, 1879.

BURI, Maximilian Von. Beiträge zur theorie des strafrechts und zum strafgesetzbuche. Leipzig: Veit, 1894.

BURI, Maximilian Von. Carl Kirchner: Buri, Maximilian Georg Wilhelm Carl Theodor Gottfried von. In: NEUE Deutsche Biographie (NDB). Ueber Causalität und deren Verantwortung: Leipzig, 1873. p. 51-52.

BURI, Maximilian Von. Die causalität und ibre strafrechtlichen beziehungen. Stuttgart: Enke, 1885. 
BURI, Maximilian Von. Einheit und mehrheit der verbrechen. Frankfurt am Main: Keip, 1968.

CAMPOS, Virgílio. Tobias Barreto e a revolução jurídica alemã: a influência de Von Jhering no pensamento tobiático. Recife: [s. n.], 1988.

CHACON, Vamireh. Da escola do Recife ao código civil. Rio de Janeiro: Organizações Simões, 1969.

COING, Helmut. Das recht als element der europäischen kultur. Heildelberg: Verlag Lambert Schneider, 1983.

CONTRERAS PELÁEZ, Francisco J. Savigny y el historicismo jurídico. Madrid: Tecnos, 2005.

CORTES, Paulo Campos. A concepção filosófica de Tobias Barreto. Rio de Janeiro: [s. n.], 1980.

CORTES, Paulo Campos. Tobias Barreto: antologia de ideia, uma revelação. Rio de Janeiro: Radial, 1974.

DAHN, Felix. Studien zur geschichte der germanischen gottesurtheile. München: [s. n.], 1857.

DAHN, Felix. Studien zur geschichte der germanischen gottesurtheile. Dillenburg: Gruber, 1998.

DAHN, Felix. Westgothische studien. Würzburg: Stahel, 1874.

DOMINGO, Rafael (Org.). Juristas universales. Barcelona: Marcial Pons, 2004.

DUVE, Thomas. European legal history: global perspectives. Max-Planck-Institute, 2013.

DUVE, Thomas. Von der Europäischen zu einer Rechtsgeschichte zu einer Rechtsgeschichte Europas in globalhistoricher perspective. In: RECHTSGESCHICHTE legal history rg 20. 2012. Available: <http://dx.doi.org/10.12946/rg20/018-071>. Acessed on: Dec., 10th, 2014. p. 18-71.

EISENHARDT, Ulrich. Deutsche rechtsgeschichte. München: Verlag C. H. Beck, 1994.

ESSER, Dirk. Gneist als zivilrechtslehrer: die pandektenvorlesung des wintersemesters: 1854-55. Paderborn; München; Wien; Zurich: Ferdinand Schöningh, 2004.

EWALD, Heinrich. Einleitung in die geschichte des volkes Israels. Goettingen: Dietrichsche Buchlandlung, 1864.

FEHR, Hans. Deutsche rechtsgeschichte. Berlin: Walter de Gruyter \& CO, 1962.

FERREIRA, Luis Pinto. Tobias Barreto e a nova escola de Recife. Recife: Imprensa Industrial, 1953.
FREUND, Leonhard. Thaten und namen: forschungen ueber staat und gesellschaft mit besonderer ruecksicht auf lorenz stein und Ruldolf Gneist. Berlin: F. Henschel, 1871.

FRÖBEL, Julius. Die gesichtspunkte und aufgaben der politik. Darmstadt: Scientia Verlag, 1971.

FRÖBEL, Julius. Die gesichtspunkte und aufgaben der politik. Leipzig: Duncker \& Humboldt, 1878.

GAMA, Affonso Dionyzio. Tobias Barreto. São Paulo: Monteiro Lobato, 1925.

GNEIST, Rudolf. Die preussische kreis-ordnung. Berlin: J. Springer, 1870.

GNEIST, Rudolf. Self-government: communalverfassung und verwaltungs-gerichte. Berlin: Springer, 1871.

GNEIST, Rudolf. Selfgovernment-communalverfassung und verwaltusgnsgerichtr in England. Berlin: Verlag Von Julius Springer, 1871.

GROSSI, Paolo. L'Europa del diritto. Roma; Bari: Laterza, 2007.

HAHN, Ericj J. Rudolf von Gneist: 1816-1895, ein politischer jurist in der bismarckzeit. Frankfurt am Main: Vittorio Klostermann, 1995.

HELLERINGER, Geneviève; PURNHAGEN, Kai. Towards a european legal culture. Baden-Baden: Nomos, 2014.

HEUSS, Alfred. Theodor mommsen und ds 19. jahrbundert. Kiel: Ferdinand Hirt, 1956.

HOKE, Rudolf. Österreichische und deutsche rechts-geschichte. Wien; Köln; Weimar: Böhlau Verlag, 1992.

HOLLWEG, August Von Bethmann. Erinnerung an Friedrich Carl Von Savigny-als rechtlehrer, staatsmann und schift. Weimar: Hermann Böhlan, 1867.

HOLLWEG, August Von Bethmann. Gerischtsverfassung und prozess des sinkenden römischen reichs. Frankfurt: Keip, 1970.

HOLLWEG, August Von Bethmann. Grundriss zu pandektenvorlesungen. Frankfurt: Broenner, 1831.

HOLLWEG, August Von Bethmann. Ueber gesetzgebung und rechtswissenschaft als aufagabe unserer zeit. Bonn: Marcus, 1876.

HOLLWEG, August Von Bethmann. Unsprung der lombardischen städtefreiheit. Amsterdam: Bonset, 1971. 
HOLLWEG, August Von Bethmann. Versuche über einzelne theile der theorie des civilprozesses. Berlin: Nicolai, 1827.

HOLTZENDORFF, Franz Von. Allgemeines staatsrecht und politik, münchen, 1874. Madrid: Fé, 1888.

HOLTZENDORFF, Franz Von. De rebus quarum commercium non est. Berolini: Schlesinger, 1852.

HOLTZENDORFF, Franz Von. Die idee des ewigen völkefriedens. Berlin: Habel, 1882.

HOLTZENDORFF, Franz Von. Eroberungen und eroberungsrecht. Berlin: Lüderitz, 1871.

HOLTZENDORFF, Franz Von. Materialen der deutschen reichsverfasssung. Berlin: C. Habel, 1873.

HOLTZENDORFF, Franz Von. Zeitglossen des gesunden menschenverstandes. München: Ackerman, 1884.

HUHN, Eugen. Politik. Leipzig: Wilhelm Grunow, 1865.

JHERING, Rudolf Von. Der zweck im recht. Leipzig: Breitkopft \& Haertel, 1883.

JHERING, Rudolf Von. Die Jurisprudenz des täglichen lebens. Iena: Verlag Von Gustav Fischer, 1927.

JOUANJAN, Olivier (Org). L'esprit de l'école historique du droit. Strasbourg: Presses Universitaires de Strasbourg, 2004.

KILLY, Walter. Deustsche biographische enzyklopädie. München; New Providence; London; Paris: K. G. Saur, 1995.

KLEINMEYER, Gerd; SCHRÖDER, Jan (Hrsg.). Deutsche und europäische juristen aus neun jabrbunderten. Heilderberg: C. F. Müller Verlag, 2008.

KLEMAN, Bernd. Rudolf Von Jhering und die historische rechtschule. Frankfurt am Main; Bern; New York; Paris: Verlag Peter Lang, 1989.

KOCH, Rainer. Demokratie und Staat bei Julius Fröbel: 1805-1893: liberales denken zwischen naturrecht und sozialdarwinismus. Wiesbaden: Franz Steiner Verlag, 1978.

KRAEPLIN, Emil. Die abschaffung des strafnaßes. Stuttgart: F. Enke, 1880.

LABOULAYE, Édouard. Essai sur la vie et les doctrines de Frédéric Charles de Savigny. Paris: A. Durand, 1842.

LAGENBECK, Whillelm. Die Lehre Von der Teilnahme am verbrechen. Jena: Mauke, 1868.
LAMMASCH, Heinrich. Auslieferungspflicht und Asylrecht. Leipzig: Duncker und Humblot, 1887.

LAMMASCH, Heinrich. Das moment objectiver gefaehrlichbeit im begriffe des verbrechensersuches. Wien: Alfred Hoelder, 1879.

LAMMASCH, Heinrich. Das recht der auslieferung wegen politischer verbrechen. Wien: Manz, 1884.

LAMMASCH, Heinrich. Die rechtskraft internationaler schiedssprüche. München: Duncker und Humblot, 1913.

LAMMASCH, Heinrich. Die Völkerrecht nach dem Kriege, Kristiania: aschehoug, 1917. Studien zum Strafgesetzentwurfe; Wien: Manz, 1891.

LAMMASCH, Heinrich. Diebstahl und beleidigung. Wien: Manz, 1893.

LAMMASCH, Heinrich. Grundris der österreichischen strafrechts. Wien: Druck und Verlag der Österr Staatsdruckerei, 1926.

LIMA, Hermes. O pensamento vivo de Tobias Barreto. São Paulo: Martins, 1943.

LIRA, Roberto. Tobias Barreto, o homem-pêndulo. Rio de Janeiro: Companhia Editora Nacional, 1937.

LOSANO, Mario. Bibliografia di Rudolf Von Jhering. Torino: Giulio Einaudi, 1968.

LOSANO, Mario. Tobias Barreto, um giurista tropicale: Tobias Barreto fra Brasile reale e Germania ideale. Roma; Bari: Laterza, 2000.

MARINI, Giuliano. La polemica sulla codificazione. Napoli: Edizioni Scientifiche Italiane, 1982.

MEYER, Hugo. Das Norddeutsche strafrecht. Halle: Waisenhauses, 1869.

MEYER, Hugo. Lehrbuch des deutschen strafrechts. Erlangen: Deichert, 1875.

MEYER, Hugo. Lehrbuch des deutschen strafrechts. Leipzig: Deichert, 1907.

MEYER, Hugo. Lebrbuch des deutsches strafrechts. Erlangen: Deichert, 1882.

MOMMSEN, Adelheid. Mein Vater: rinnerunger an Theodor Mommsen. München: Matthes \& Seitz Verlag, 1992.

MOMMSEN, Theodor. Roemisches staatsrecht. Leipzig: Hirzel, 1876. 
MOMMSEN, Theodor. Römisches strafrecht. Graz: Akademische Druck-U. Verlagsansalt, 1955.

MONT'ALEGRE, Omer. Tobias Barreto. Rio de Janeiro: Vecchi, 1939.

MORAES FILHO, Evaristo de. Medo à utopia: o pensamento social de Tobias Barreto e Silvio Romero. Brasília, Rio de Janeiro: Nova Fronteira, INL, 1985.

MUTHER, Theodor. Die reform des juristischen unterrichts. Frankfurt: Keip, 1968.

MUTHER, Theodor. Die reform des juristischen unterrichts. Weimar: Böhlau, 1873.

MUTHER, Theodor. Roemisches und kanonisches recht im deutschen mittelalter. Rostock: Kuhn, 1871.

PAIM, Antonio. A filosofia da escola do Recife. Rio de Janeiro: Saga, 1966.

PELÁEZ, Manuel J. (Ed.). Dicionario crítico de juristas españoles, portugueses y latinoamericanos. Zaragoza y Barcelona: Cometa, 2005.

PELÉZ, Manuel J.; BRÁS TEIXEIRA, Antonio. Tobias Barreto. In: DOMINGO, Rafael (Org.). Juristas universales. Madrid, Barcelona: Marcial Pons, 2004. p. 135-137.

PEREIRA, Virgílio de Sá. Tobias Barreto. Rio de Janeiro: Revistas dos Tribunais, 1917.

RAYM, Rudolf. Die deutsche nationalversammlung bis zu september-ereignissen. Frankfurt: Carl Jügel, 1848.

REALE, Miguel. Estudos de filosofia brasileira. Lisboa: Guimarães Editores, 1994.

REALE, Miguel. Figuras da inteligência brasileira. São Paulo: Siciliano, 1994.

RODRIGUES JÚNIOR, Otavio Luís. A Influência do $B G B$ e da doutrina alemã no direito civil brasileiro do século XX. São Paulo: Revista dos Tribunais, 2013. v. 938.

ROMERO, Nelson. Tobias Barreto. Rio de Janeiro: Globo, 1943 .

ROSENBERG, Hans. Rudolf Haym und die anfänge des klassischen liberalismus. München: Oldenbourg, 1933.

ROSSHIRT, Conrad Franz. Beiträge zum gemeinen deutschen

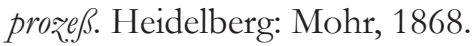

ROSSHIRT, Conrad Franz. Canonisches recht. Schaffhausen: Hurter, 1857.
ROSSHIRT, Conrad Franz. Einleitung in das erbrecht und darstellung des ganzen intestat-erbrechts, besonders nach römischen quellen. Landshut: Krüll, 1831.

ROSSHIRT, Conrad Franz. Ueber die tendenz des prätorischen rechts und über das verbältniss desselben zum civilrechte. Erlangen: Hilpert, 1812.

ROSSHIRT, Conrad Franz. Zu den kirchenrechtlichen quellen des ersten jabrtausends und zu denpseudoisidorischen decretalen. Heidelberg: Mohr, 1849.

ROSSIRT, Conrad Franz. Entwickelung der grundsätze des strafgesetzbuch für das deutsche reich unda einführunggsgeset: Berlin: Carl Heymanns, 1872.

RUBO, Ernest Traugott. Kommentar über das strafgeset乏̧ buch für das deutsche reich. Berlin: Carl Heimanns Verlag, 1872.

RUBO, Ernst Traugott. Kommentar über das strafgesetzbuch für das deutsche reich. Berlin, 1879.

RUBO, Ernst Traugott. Kommentar über das strafgesetzbuch für das deutsche reich. Frankfurt: Keip, 1992.

SAMUELY, Adolf. Artikel 50 der schweirzerischen bundesverfassung vom 20. mai 1874. Bern: Buchdrukerei von Jent \& Reinert, 1874.

SAMUELY, Adolf. Das prinzip der ministerverantwortlichkeit in der constitutionellen monarchie. Berlin: J. Springer, 1869.

SAVIGNY, Freidrich Karl Von. De la vocación de nuestro siglo para la legislacion y la ciencia del derecho. Buenos Aires: Arengreen, 1946.

SCHÜTZE, Theodor Reinhold. Die nothiwendige theilnahme am verbrechen, Leipzig: J. M. Gebhardt, 1869.

SCHÜTZE, Theodor Reinhold. Lehrbuch des deutschen strafrecbts. Leipzig: J. M. Gebhardt, 1874.

SCHWARZE, Friedrich Oskar. Commentar zum strafgesetz̧buch für das dentsche reich. Leipzig: Fue, 1873.

SOSA WAGNER, Francisco. Maestros alemanes del derecho público. Barcelona: Marcial Pons, 2005.

SÖTVÖS, Joseph. Der einfluss der herrschenden ideen des 19 jabrbunderts auf den staat. Leipzig: F. U. Brockhaus, 1854.

STEIN, Peter; SHAND, John. Legal values in western society. Edinburgh: Edinburgh University Press, 1974.

STOBBE, Otto. Die juden in deutschland während des mittelalters in politischer, socialer und rechtlicher beziebung, verlagsort. Berlin: Lamm, 1923. 
STOBBE, Otto. Geschichte der deutschen Rechtsquellen. Leipzig, 1860.

STOBBE, Otto. Hanbuch des deutschen privatrechts. Berlin: W. Hertz, 1871-1878. v. 3.

STOBBE, Otto. Zur Geschichte des deutschen vertragsrechts, leipzig, 1855 zur geschichte des deutschen vertragsrechts. Frankfurt: Minerva, 1969.

STOLLEIS, Michael (Org.). Juristen- ein biographisches lexicon von der antike bis zum 20 jahrbundert. München: Beck, 2001.

STOLLEIS, Michael. Public law in Germany, 1800-1914. New York: Oxford, 2001.
STÖVÖS, Joseph. Der einfluss der herrschenden ideen des 19 jabrbunderts auf den staat. Wien: Jasper, Hügel \& Manz, 1851.

STRICKER, Salomon. Physiologie des rechts. Wien: Teoplitz \& Deutick, 1884.

WATSON, Peter. The German genius: Europe's third renaissance, the second scientific revolution and the twentieth century. London: Simon \& Schuster, 2010.

WESEL, Uwe. Geschichte des rechts in europa-von den griechen bis zum vertrag von lissabon. München: Verlag C. H. Beck, 2010. 
Para publicar na Revista de Direito Internacional, acesse o endereço eletrônico www.rdi.uniceub.br ou www.brazilianjournal.org.

Observe as normas de publicação, para facilitar e agilizar o trabalho de edição. 